\title{
Beyond the Bounty: Breadfruit (Artocarpus altilis) for food security and novel foods in the $21^{\text {st }}$ Century
}

\author{
A.M.P. Jones, D. Ragone, N.G. Tavana, \\ D.W. Bernotas, and S.J. Murch
}

\section{Research}

\begin{abstract}
The Food and Agriculture Organization recently reported that the number undernourished people has reached a record high of 1.02 billion, most prevalent in the tropics. Breadfruit, Artocarpus altilis (Parkinson) Fosberg, is an underutilized Oceanic staple crop long recognized for its potential to alleviate hunger in tropical climates. Breadfruit can be grown sustainably with minimal agricultural inputs and can be multicropped with high value cash crops such as coffee, pepper, or vanilla. A great diversity of cultivars with varying nutritional and agronomic characteristics exists, yet few cultivars are widely cultivated. Recent developments in micropropagation have made possible large scale propagation and dissemination but to fully utilize this resource, a deeper understanding of the nutritional characteristics, and the development of new products and markets are needed. This review will highlight and describe the state of our current knowledge and the potential for breadfruit as a sustainable crop to provide new foods for Western markets and food security for the growing global population.
\end{abstract}

\section{Introduction}

Food security was defined at the World Food Summit held in Rome, 1996, as "when all people at all times have access to sufficient, safe, nutritious food to maintain a healthy and active life" (World Bank 2007). During this meeting, representatives from 185 countries pledged to reduce world hunger to $50 \%$ of $1990-1992$ levels by the year 2015. However, since this meeting there has been an unfortunate increase in hunger worldwide (FAO 2008) and the estimated number of undernourished people has increased to a record high of 1.02 billion, approximately 1 in 6 people (FAO 2009a). One of myriad factors responsible for this trend is the dramatic increase in food prices that occurred during the last decade. Since 2000, the overall food price index has increased $120 \%$, led by an increase of $184 \%$ for cereals (FAO 2008). In addition to overall undernourishment, specific vitamin and mineral deficiencies are prevalent in many regions and represent a significant threat to food security. Seventy percent of the undernourished population live in the rural areas of developing nations and depend primarily on agriculture for their livelihood (World Bank 2007). As such, agricultural development must play a leading role in the alleviation of world hunger and to increase global food security.

Breadfruit (Artocarpus altilis Parkinson (Fosberg)) is a traditional staple crop grown for its starchy fruit throughout Oceania (Ragone 1997). Breadfruit yields of 6 t/ha (edible dry weight) have been reported (Sauerborn 2002). This is an impressive yield compared to the current predominant staple crops, with average yields of $4.11 \mathrm{t} / \mathrm{ha}$ for rice

\section{Correspondence}

A.M.P. Jones, Biology, University of British Columbia Okanagan, 3333 University Way, Kelowna, British Columbia, V1V 1V7, CANADA.

D. Ragone, N.G. Tavana National Tropical Botanical Garden, 3530 Papalina Road, Kalaheo, Hawai i, U.S.A.

D.W. Bernotas, Department of Economics, University of California, San Diego, 9500 Gilman Drive \#0508 La Jolla, California 92093-0508, U.S.A.

S.J. Murch, Chemistry, University of British Columbia Okanagan, 3333 University way, Kelowna, British Columbia, V1V 1V7, CANADA.

Ethnobotany Research \& Applications 9:129-149 (2011)

Published: March 26, 2011 
(2005), $4 \mathrm{t} /$ ha of corn (1990-2000) and $2.6 \mathrm{t} / \mathrm{ha}$ of wheat (1990-2000) (Calpe 2007, FAO 2009c, d). Breadfruit is also a relatively low input crop and is a key component of some agroforestry systems (Fownes \& Raynor 1993). Despite the high yields, potential for low input and sustainable production systems, breadfruit remains a marginal crop outside of the Pacific region (Ragone 1997). The millennia of selective breeding by the indigenous peoples of Oceania has resulted in enormous variability in morphological, agronomic, and nutritional characteristics among cultivated varieties (Zerega et al. 2004, 2006). Many of these cultivars are at risk of disappearing due to the loss of traditional indigenous knowledge, shifts in agricultural production, natural disasters and urban development. In this review the potential of breadfruit as a staple crop that has the potential to significantly improve global food security and help avert the significant food shortages that loom in the near future will be discussed.

\section{Breadfruit: An Historical Perspective}

While much of the temperate world may know breadfruit as an obscure plant seen on tropical vacations or in movies and books, the potential of this plant as a valuable food resource has long been recognized. The Spanish collected breadfruit and introduced it to the Philippines during the 17 th century, but it was not until the 1700s that more widespread dissemination of the crop outside of Oceania occurred (Barrau 1976, Ragone 1997, Smith et al. 1992). This spread was spurred by the writings of Sir Joseph Banks who recommended the introduction of breadfruit to the Caribbean and other tropical colonies as a source of food after seeing it on his voyage on HMS Endeavour from 1768-1771 (Beaglehole 1962). After his failed attempt to introduce Tahitian breadfruit to the Caribbean following the famed mutiny on the HMS Bounty, Captain William Bligh led a subsequent expedition and successfully transported more than 600 breadfruit plants to Jamaica and St. Vincent in 1772 (Powell 1977, Ragone 1997). Soon after, French contemporaries introduced breadfruit to many of their tropical colonies. Breadfruit is now cultivated to a limited extent in over 80 countries worldwide including regions of Africa, Australia, South America, South and South-East Asia.

Breadfruit is a well known part of daily life in much of Oceania (Melanesia, Micronesia and Polynesia) where it has been cultivated as a staple crop for 2000-3000 years (Zerega et al. 2004, 2005) and plays a significant role in many aspects of daily life. There are many legends about the origin of breadfruit from various parts of Oceania (Ragone 1991) that often describe the origins of the breadfruit tree arising from a man or god, and providing sustenance during times of famine. The following example was originally recorded on Raiatea, based on an oral account in 1887 (Henry \& Orsmond 1928, Ragone 1991):

"During a time of famine long ago, red clay was the only food. A Raiatean man took his wife and four chil- dren into the mountains where they hid in a cave and ate ferns. He told his wife to go outside in the morning and she would see "my hands become leaves, the trunk and two branches my body, and the round fruit my head and the core inside, my tongue." In the morning, a beautiful tree stood as her husband had foretold. That valley is now called Tuauru, the place of breadfruit. She roasted the fruit, soaked it in a nearby stream and peeled it. She fed her family, but did not first make a customary offering to the king. When she prepared the fruit, pieces of the core and peel washed down stream. Servants of the king were catching shrimp in the stream. They found and ate the pieces. They were curious about this strange food and searched until they found the tree. They asked the woman what it was and she replied uru. She explained how it had arisen from the body of her husband who wanted to feed his family. The servants admired the tree which was covered with fruit of all the cultivars. The tree was taken down from the mountain and planted in her family's marae. A root was broken off and taken to the island of Tahaa where it grew. Ripe fruits were taken to the king and he liked it so much he ordered his servants to bring the tree and its owner to him. While they were transplanting the tree, woman begged for some roots and planted them in a valley which became known as Maiore. The family wept for their lost tree, but new trees soon arose from the roots left behind."

Throughout Oceania there are hundreds of unique cultivars of breadfruit exhibiting great diversity in many attributes (Morton 1987, Ragone 1997). For example, there are 132 cultivars documented from Vanuatu (Walter 1989), 70 from Fiji (Koroveibau 1967, Morton 1987), 50 from Pohnpei (Raynor \& Fownes 1991, Ragone \& Raynor 2009), more than 30 from Tahiti (Wilder 1928) and over 40 from Samoa (Ragone et al. 2004). Cultivars are named and valued based on morphological characteristics, cooking and storage qualities of the fruit, and agronomic characteristics. Cultivars in Samoa are generally named using a binomial system, composed of the generic name 'ulu, the local name for breadfruit, followed by a specific epithet that often provides a description of the fruit or cultivar in general (Ragone et al. 2004). However, the general term ulu is often not included for cultivars in which it is implicitly understood. For example, Ma`afala, the most commonly known cultivar in Samoa, is not typically referred to as 'ulu ma'afala, but it is understood and may be referred to as such if needed (Ragone et al. 2004). A similar naming system is used in Pohnpei where the generic name for breadfruit is mahi and most cultivar names are binomials with mei or mein included as part of the name, e.g., Meiuhpw or Meinpadahk. Only a few names, such as Lipet or Luhkual, are monomials. Pohnpeians classify all breadfruit into two types based on skin texture: (I) smooth (meiniwe) or (II) rough (meinsahrek) (Ragone \& Raynor 2009). 


\section{Jones et al. - Beyond the Bounty: Breadfruit (Artocarpus altilis) for food security and novel foods in the $21^{\text {st }}$ Century}

As indigenous peoples in Oceania are becoming more modernized and shifting away from traditional foods in exchange for imported crops, much of the information about cultivars and breadfruit in general is being lost; for example a 20-29 year old Samoan knows an average of 6.1 cultivars while a 60-69 year old Samoan knows an average of 9.2 (Ragone et al. 2004). Many other aspects of traditional knowledge such as cultivation and storage techniques are also threatened by cultural erosion (Lee et al. 2001, Ragone et al. 2004).

Often overshadowed by its value as a food crop, breadfruit has long been valued for a variety of medicinal and other secondary applications. The wood is used in the construction of homes and canoes, is prized for its resistance to termites, and is often used for wood carvings (Ragone 1991). The sticky latex has been used as birdlime, as an adhesive/caulking in canoes and in traditional medicine. The bast fibers were used for the production of cloth and cordage, with specific cultivars desirable due to the high-quality cloth that they produced. Various parts of the plant, including crushed leaves, latex, bark, and roots, have been used to treat a variety of ailments ranging from skin conditions to high blood pressure (Table 1). Recent research from Indonesia has reported the patenting of phytochemicals isolated from leaf tissue of bread-

Table 1. Traditional medicinal uses of breadfruit (Artocarpus altilis (Parkinson) Fosberg).

\begin{tabular}{|c|c|c|c|c|}
\hline Location & Plant Part & Preparation & Use & Reference \\
\hline Vanuatu & Latex & $\begin{array}{l}\text { Mix equal amount of latex } \\
\text { from Ficus adenosperma and } \\
\text { Artocarpus altilis and drink }\end{array}$ & Menorrhagia & $\begin{array}{l}\text { Bourdy \& } \\
\text { Walter } 1992\end{array}$ \\
\hline $\begin{array}{l}\text { Vanuatu } \\
\text { (Mota Lava) }\end{array}$ & Latex & Not documented & Diarrhea & $\begin{array}{l}\text { Navarro et } \\
\text { al. } 2007\end{array}$ \\
\hline $\begin{array}{l}\text { Pacific } \\
\text { Islands }\end{array}$ & Latex & Rubbed into skin & $\begin{array}{l}\text { Broken bones } \\
\text { and sciatica }\end{array}$ & Ragone 1997 \\
\hline $\begin{array}{l}\text { Pacific } \\
\text { Islands }\end{array}$ & Latex & Diluted and taken internally & $\begin{array}{l}\text { Diarrhea, dysentry } \\
\text { and stomach aches }\end{array}$ & Ragone 1997 \\
\hline $\begin{array}{l}\text { Pacific } \\
\text { Islands }\end{array}$ & $\begin{array}{l}\text { Latex and/or } \\
\text { crushed leaves }\end{array}$ & Rubbed into skin & $\begin{array}{l}\text { Skin ailments and } \\
\text { fungal infections }\end{array}$ & Ragone 1997 \\
\hline $\begin{array}{l}\text { Pacific } \\
\text { Islands }\end{array}$ & $\begin{array}{l}\text { Latex and/or } \\
\text { crushed leaves }\end{array}$ & Latex and/or juice from crushed leaves & Ear infections & Ragone 1997 \\
\hline $\begin{array}{l}\text { Western } \\
\text { Pacific }\end{array}$ & $\begin{array}{l}\text { Leaf bud } \\
\text { and latex }\end{array}$ & $\begin{array}{l}\text { Chew and swallow from one to five fresh } \\
\text { leaf buds, then drink one small glass of } \\
\text { fresh latex. Repeat one to three times } \\
\text { per day, until recovery is complete }\end{array}$ & $\begin{array}{l}\text { Ciguatera } \\
\text { poisoning }\end{array}$ & $\begin{array}{l}\text { Bourdy et } \\
\text { al. } 1992\end{array}$ \\
\hline $\begin{array}{l}\text { Western } \\
\text { Pacific }\end{array}$ & Leaf Buds & $\begin{array}{l}\text { Mix fresh leaf buds together } \\
\text { with coconut oil }\end{array}$ & $\begin{array}{l}\text { Ciguatera } \\
\text { poisoning }\end{array}$ & Lobel 1979 \\
\hline $\begin{array}{l}\text { Trinidad } \\
\text { and Tobago }\end{array}$ & Leaves & Not documented & Hypertension & Lans 2006 \\
\hline Suriname & Leaves & Not documented & Fever & Bipat et al. 2008 \\
\hline Rotuma & Leaves & Not documented & $\begin{array}{l}\text { Oral inflammation } \\
\text { and pain }\end{array}$ & McClatchey 1993 \\
\hline Taiwan & Leaves & Not documented & $\begin{array}{l}\text { Liver disease } \\
\text { and fever }\end{array}$ & Ragone 1997 \\
\hline West Indies & Leaves & Tea made from yellowing leaves & $\begin{array}{l}\text { High blood } \\
\text { pressure, and } \\
\text { perhaps diabetes }\end{array}$ & Ragone 1997 \\
\hline $\begin{array}{l}\text { Vanuatu } \\
\text { (Mota Lava) }\end{array}$ & Young leaves & Not documented & Headaches & $\begin{array}{l}\text { Navarro et } \\
\text { al. } 2007\end{array}$ \\
\hline $\begin{array}{l}\text { Vanuatu } \\
\text { (Aneithyum) }\end{array}$ & Young leaves & Not documented & Urinary infections & $\begin{array}{l}\text { Navarro et } \\
\text { al. } 2007\end{array}$ \\
\hline $\begin{array}{l}\text { Vanuatu } \\
\text { (Mota Lava) }\end{array}$ & \begin{tabular}{|l} 
Male \\
inflorescence
\end{tabular} & Burned & Mosquito repellant & $\begin{array}{l}\text { Navarro et } \\
\text { al. } 2007\end{array}$ \\
\hline
\end{tabular}




\begin{tabular}{|l|l|l|l|l|}
\hline Location & Plant Part & Preparation & Use & Reference \\
\hline $\begin{array}{l}\text { Not } \\
\text { documented }\end{array}$ & $\begin{array}{l}\text { Male } \\
\text { inflorescence }\end{array}$ & Roasted, powdered and rubbed on gums & Aural pain relief & Ragone 1997 \\
\hline $\begin{array}{l}\text { Not } \\
\text { documented }\end{array}$ & Root & Not documented & Purgative & Ragone 1997 \\
\hline $\begin{array}{l}\text { Not } \\
\text { documented }\end{array}$ & Root & Mascerated and used as a poultice & Skin ailments & Ragone 1997 \\
\hline $\begin{array}{l}\text { Western } \\
\text { Pacific }\end{array}$ & Shoots & Fluid pressed from the shoots & $\begin{array}{l}\text { Ciguatera } \\
\text { poisoning }\end{array}$ & Weiner 1984 \\
\hline Samoa & Leaves & $\begin{array}{l}\text { The juice from the chewed or } \\
\text { crushed leaf petiole is dripped } \\
\text { into the afflicted eye }\end{array}$ & Injured eyes & Whistler 2001 \\
\hline Samoa & Bark/root & $\begin{array}{l}\text { An infusion from the scraped bark or } \\
\text { roots is sometimes taken as a potion }\end{array}$ & $\begin{array}{l}\text { Urinary tract } \\
\text { problems }\end{array}$ & Whistler 2001 \\
\hline Samoa & $\begin{array}{l}\text { Small } \\
\text { branches }\end{array}$ & $\begin{array}{l}\text { The smoke from a hollow, burning } \\
\text { breadfruit twig is sometimes blown into } \\
\text { the anal area of an infant for treating } \\
\text { childhood ailments collectively called ila. }\end{array}$ & lla & Whistler 2001 \\
\hline $\begin{array}{l}\text { Vanuatu } \\
\text { (Mota Lava) }\end{array}$ & Unknown & $\begin{array}{l}\text { Not documented } \\
\text { Shock magic, }\end{array}$ & $\begin{array}{l}\text { Navarro et } \\
\text { al. 2007 }\end{array}$ \\
\hline
\end{tabular}

fruit trees for the prevention of stroke and cardiovascular diseases (Sagita 2009). The use of breadfruit in medicine developed in traditional breadfruit growing regions in Oceania and was spread, or more likely developed independently, in areas where it is a relatively recent introduction such as the Caribbean and Taiwan (Lin et al. 1992, Mclntoch \& Manchew 1993). The widespread use of this plant species in medicine, the possible independent development of these practices in isolated regions, and more recent empirical evidence suggest validity in its value in traditional medicine and potential for modern drug discovery.

\section{Ecological Requirements}

Breadfruit is well adapted to the wet tropics, doing best at temperatures ranging from $21-32{ }^{\circ} \mathrm{C}$ with an annual rainfall of $1525-2540 \mathrm{~mm}$ and adequate drainage (Ragone 1997, 2006a). Cooler temperatures often result in low yields and increased plant mortality (Lebegin et al. 2007). Although breadfruit requires relatively high levels of rainfall, it can survive droughts of 3-4 months after the tree is established (Elevitch \& Wilkinson 2000). Tolerance to soil salinity is known to vary among $A$. altilis, A. mariannensis and hybrid cultivars (Ragone 1997, 2006a, Ragone \& Manner 2006). Artocarpus mariannensis is often found on small atolls and is reportedly more tolerant of soil salinity as well as salt spray from the ocean than $A$. altilis. However, this difference has not been quantitatively evaluated, nor have comparisons between $A$. altilis and $A$. altilis $\times A$. mariannensis hybrids.

\section{Taxonomy and Botanical Description}

Breadfruit is a tropical tree in the genus Artocarpus in the Moraceae (mulberry/fig) family (Figure 1; (Fosberg 1960, Jarrett 1959)). The genus is comprised of approximately 50-60 species native to South/South-East Asia, and Australasia (Kanzaki et al. 1997, Zerega et al. 2004). It is sometimes further divided into two subgenera, Artocarpus, which includes breadfruit, and Pseudojaca (Kanzaki et al. 1997). The common name 'Breadfruit' typically refers to the species Artocarpus altilis (Parkinson) Fosberg, but is occasionally used in reference to $A$. camansi or $A$. mariannensis. Artocarpus altilis is classified as a 'cultigen', a domesticated species of plant that is not found in the wild, domesticated from breadnut ( $A$. camansi) (Zerega et al. 2004, 2005). Artocarpus camansi is native to Papua New Guinea and potentially the Moluccas and Philippines (Coenan \& Barrau 1961, Zerega et al. 2004). Artocarpus mariannensis, another closely related species, is native to the Mariana Islands and Palau. Physical characteristics and Amplified Fragment Length Polymorphism (AFLP) analyses suggest that many cultivars of breadfruit are interspecific hybrids of $A$. altilis $\times A$. mariannensis (Fosberg 1960, Zerega et al. 2004, 2005). Artocarpus altilis $\times$ A. mariannensis hybrid cultivars are found throughout Micronesia, but are absent from Melanesia and Polynesia with the exception of a few recently introduced cultivars (Fosberg 1960, Zerega et al. 2004). The existence of hybrid cultivars was originally proposed by Fosberg and later supported based on human migration patterns (Fosberg 1960, Zerega et al. 2004) as well as morphological and molecular analysis (Zerega et al. 2005). Phylogenetic analysis based on morphological characteristics and molecular evidence demonstrated that the three species be- 


\section{Jones et al. - Beyond the Bounty: Breadfruit (Artocarpus altilis) for food security and novel foods in the $21^{\text {st }}$ Century}

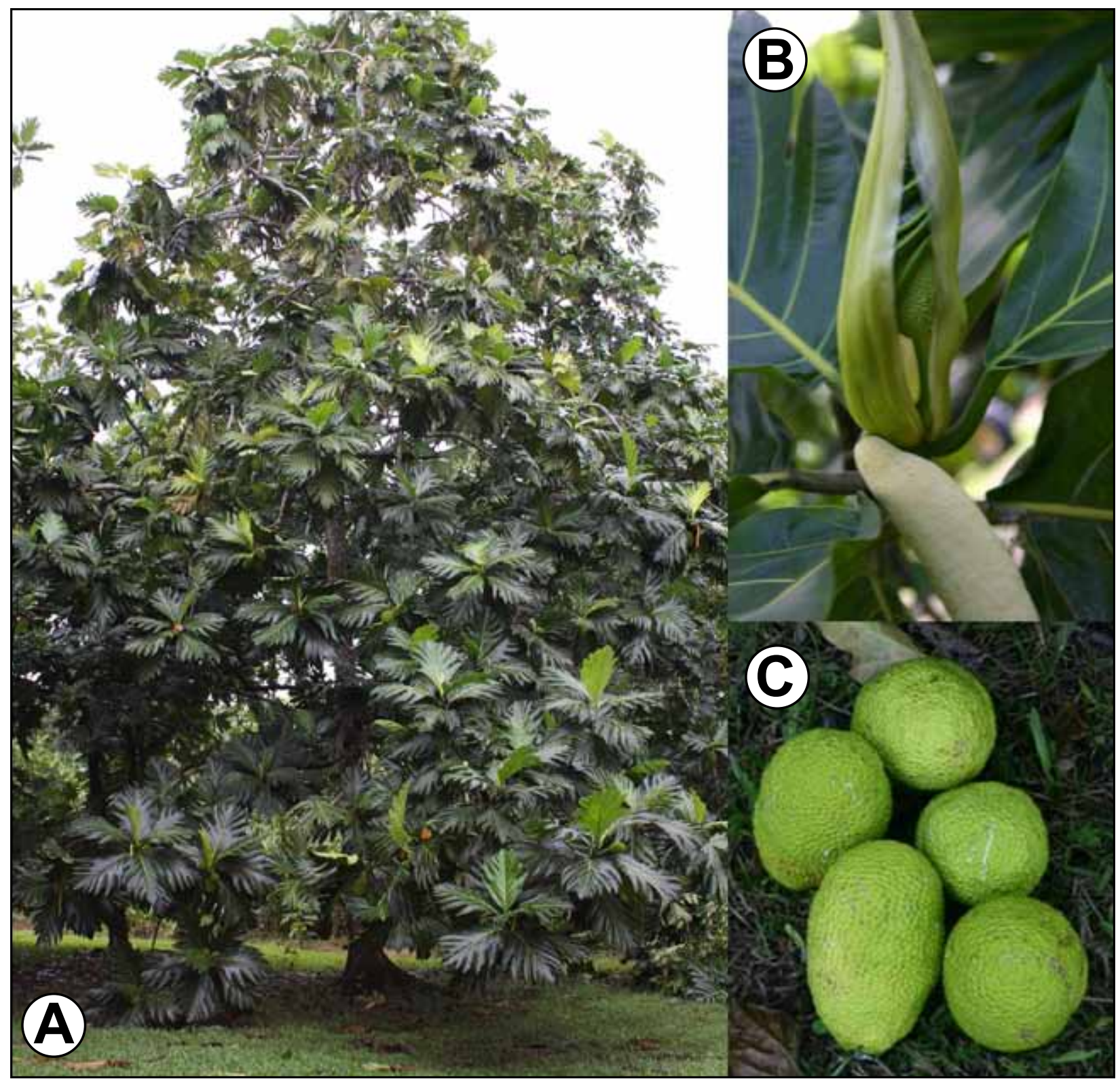

Figure 1. Morphology and growth of breadfruit (Artocarpus altilis (Parkinson) Fosberg trees. A. Trees grow from 30-60 tall and live for 35-50 years or longer when properly maintained. B. Male flower (bottom arrow) and fruit (top arrow) develop at the terminal apex of individual branches. C. Mature fruit are $1.0-3 \mathrm{~kg}$ in weight and exude a sticky white latex when first harvested.

long in a closely related monophylic group within the genus (Zerega et al. 2004, 2005, 2006).

Seeded varieties of breadfruit are commonly found in and around Papua New Guinea and throughout Melanesia, while seedless cultivars predominate in the Polynesian islands (Ragone 2001, Zerega et al. 2004). As human populations migrated throughout the Pacific islands, they developed and maintained their own unique cultivars. This has given rise to hundreds of distinct phenotypes often specific to individual islands. The distribution and development of these cultivars has been used to help elucidate human migration throughout Polynesia and Micronesia from Melanesia (Zerega et al. 2004).

\section{Artocarpus altilis (Parkinson) Fosberg}

Artocarpus altilis has previously been referred to as $A$. incisus (Thunb.) L.f. and $A$. communis J.R. Forst. \& G. Forst., however, $A$. altilis is currently accepted (Fosberg 
1941, 1960, Ragone 1997). Artocarpus altilis is a moderately large evergreen tree generally growing from 15$20 \mathrm{~m}$, but sometimes reaching over $30 \mathrm{~m}$ tall (Niering 1963, Ragone 1997, 2006a). During development, terminal buds are encased by two large stipules up to $30 \mathrm{~cm}$ long that senesce as the buds emerge (Ragone 1997). Leaf morphology is highly variable between cultivars and to some degree even within an individual tree. The leaves are large, measuring between 22.8-90 cm long and 20-50 $\mathrm{cm}$ wide (Morton 1987, Zerega et al. 2005), are broadly obovate to broadly ovate in shape, and vary from almost entire to deeply lobed with pinnate venation (Ragone 1997). The abaxial surface of the leaf is often pubescent, with white or reddish-white trichomes found primarily along the veins. White latex is produced throughout the plant in mostly unarticulated laticifers, and is exuded upon mechanical injury (Harvey 1999).

Breadfruit trees are monoecious, with inflorescences comprised of about 1500-2000 individual florets connected to the receptacle (Figure 1B). Male inflorescences are elongated and club shaped, measuring $12.5-30 \mathrm{~cm}$ in length (Morton 1987, Ragone 2006a, Zerega et al. 2005). Female inflorescences are globose and develop into a multiple fruit referred to as a syncarp (Jarrett 1976). Male inflorescences appear earlier than female inflorescences providing a temporal separation preventing self pollination (Heard 1999, Sharma 1965). It is suspected that breadfruit is wind pollinated due to the reported lack of scent; however, some researchers have reported a distinct floral aroma (Heard 1999, Ragone 2006a). Additionally, bees have been observed visiting flowers and fruit, but their significance regarding pollination is not known (Brantjes 1981). Hand pollination of breadfruit inflorescences is sometimes done to improve fruit set (Heard 1999). As with leaves, fruit morphology displays a great diversity in size, shape and other attributes. Generally, fruit are about 12 $\mathrm{cm}$ long, $12-20 \mathrm{~cm}$ wide and weigh $1-2 \mathrm{~kg}$, but some cultivars can produce fruit weighing up to $6 \mathrm{~kg}$ (Figure 1C; Ragone 1997, 2006a, Zerega et al. 2005). The skin varies in color from light green to yellow at maturity while the flesh can range from creamy white to yellow. The individual sections of the fruit surface can be relatively flat or conical rising up to $5 \mathrm{~mm}$ above the fruit surface. Thus, the fruit can be smooth, bumpy, or spiked (Ragone 2006a, Zerega et al. 2005). Many cultivars of $A$. altilis are triploid, and produce no seeds $(3 n=2 x=\sim 84)$ (Murch et al. 2007, Ragone 2001), while others are diploid $(2 n=2 x=\sim 56)$ and produce few to several seeds. A. camansi and A. mariannensis are both seeded diploids with $2 \mathrm{n}=2 \mathrm{x}=\sim 56$ (Ragone 1997, 2001).

\section{Artocarpus camansi Blanco}

Artocarpus camansi, commonly referred to as seeded breadfruit or breadnut, resembles $A$. altilis to a large extent. Some of the distinguishing characteristics of breadnut are that the leaves are highly pubescent, covered in straight pale trichomes, the fruit contain numerous achenes (Bennett \& Nozzolillo 1987, Roberts-Nkrumah 2002), and the fruit surface is covered in flexible spines measuring 5-12 mm (Ragone 2006d, Reeve 1974, Zerega et al. 2005). The principal difference is the high number of large, hard-coated seeds prevalent in the fruit. A key to differentiate these species has been developed (Zerega et al. 2005)

\section{Artocarpus mariannensis Trécul}

Artocarpus mariannensis, known as dugdug, ebechei and other common names in various regions is also similar to breadfruit in many respects, but can be distinguished using the aforementioned key (Ragone \& Manner 2006, Zerega et al. 2005). Some of the distinguishing characteristics include entire leaf margins or 3-7 lobes in the distal third of the leaf, abundance of reddish brown trichomes on the midrib and abaxial veins, and the fruit is often irregularly shaped with dark green skin, even when ripe. Also, the individual fruit that comprise the syncarp are not fused except near the receptacle and near the skin (Ragone \& Manner 2006). Distinguishing dugdug (A. mariannensis) from breadfruit ( $A$. altilis) is relatively easy to the well-trained eye, however, $A$. mariannensis $\times A$. altilis hybrids can display intermediate characteristics making their identification more complex (Fosberg 1960, Ragone \& Manner 2006).

\section{Genetic Diversity and Germplasm Conservation}

Breadfruit is included as one of the 35 priority crops listed in the International Treaty on Plant Genetic Resources for Food and Agriculture for their potential impact on food security and food interdependence (FAO 2009b). Furthermore, The Global Crop Diversity Trust has developed a conservation strategy that identifies breadfruit as one of the high priority crops (Ragone 2007). Genetic diversity is greatest in Micronesia and Melanesia where seeded cultivars predominate, with less diversity found among the seedless triploid cultivars that typify the Polynesian cultivars (Ragone 2001, Zerega et al. 2005). However, despite the more limited genetic diversity within Polynesia, there is a high degree of morphological diversity and many distinct cultivars. The breadfruit trees introduced outside of Oceania are primarily derived from a select few seedless cultivars from eastern Polynesia and represent a very small amount of the existing diversity (Ragone 2007). Breadnut, $A$. camansi, has also been introduced outside of its native range and is cultivated on a small scale in the Caribbean, South America, South-East Asia and parts of Africa (Ragone 2006b). As with breadfruit, the introduced breadnut plants represent a very small amount of the genetic potential that exists. Little work has been conducted on cultivar development or comparison in breadnut (Ragone 2006b). Genetic diversity of breadfruit is manifested as phenotypic variation in leaf size and shape, seasonality of production, disease resistance, salinity tolerance, nutrient con- 


\section{Jones et al. - Beyond the Bounty: Breadfruit (Artocarpus altilis) for food security and novel foods in the $21^{\text {st }}$ Century}

tent, fruit size, shape, flavour, and texture. It is likely that breadfruit yields, nutrient content, shelf life and palatability could be improved with detailed descriptions and judicious selection of cultivars to be planted. It may also be possible to expand suitable breadfruit growing areas by identifying cultivars that display traits such as salinity and drought tolerance that would allow them to grow in traditionally marginal environments (Ragone 2007).

Oceanic societies have shifted away from subsisting on locally produced traditional crops, incorporating larger amounts of imported/introduced food such as rice and wheat (Englberger et al. 2007, Morton 1987, Ragone 2007). For example, between 2001-2003 wheat and rice accounted for approximately 20 percent of the average Samoan diet and 40 percent of the average Fijian diet (FAO 2007). This dramatic shift in dietary intake indicates a reduced emphasis on the cultivation and the subsequent in-situ conservation of the immense number of cultivars that exist. Breadfruit trees are also susceptible to natural phenomena such as hurricanes and droughts. With fewer trees being cultivated the probability of losing genetic diversity during a natural disaster increases significantly. Many cultivars are endemic to individual islands and relatively isolated events can represent tragic genetic and cultural erosion.

In order to preserve the genetic diversity of breadfruit, several ex-situ germplasm collections have been established (Ragone 2007). However, many of these collections lack proper cultivar identifications and some have diminished due to lack of funding and maintenance (Ragone 2007). The largest active germplasm collection is located in the Kahanu Garden, Hana, Hawai'i, managed by the Breadfruit Institute (BFI), of the National Tropical Botanical Gardens (NTBG). This collection is comprised of 265 trees representing about 120 well-documented cultivars. However, ex-situ germplasm collections remain vulnerable to natural disasters, disease, and other deleterious events
(Murch et al. 2007, Shi et al. 2007). In order to add a measure of security to the NTBG collection and enable large scale cultivar dissemination, the collection is being replicated in-vitro (Murch et al. 2007, Shi et al. 2007). These efforts are complicated by the high rate of endophytic bacterial and fungal contamination in wild trees (Murch et al. 2007, Rouse-Miller \& Duncan 2000, Tuia et al. 2007) and differential responses to inductive stimuli requiring optimized regeneration protocol for each cultivar (Shi et al. 2007). Despite these difficulties, 17 cultivars have been successfully incorporated into an in-vitro collection, with an additional 24 in the preliminary stages.

\section{Breadfruit Phytochemistry}

Plants produce a wide range of phytochemicals loosely defined as secondary metabolites, compounds not usually necessary for basic metabolism but often function to attract animals or prevent infection, parasitism and predation (Simpson \& Ogorzaly 2000). The Artocarpus genus is known to produce a large number of secondary metabolites, and is specifically rich in phenylpropanoids such as flavonoids and flavones (Nomura et al. 1998). Artocarpus altilis (breadfruit) is no exception with over 130 compounds identified in various organs of the tree, more than 70 of which are derived from the phenylpropanoid pathway (Table 2). Many of the isolated compounds have been found to exhibit biological activity including inhibition of platelet aggregation, anti-bacterial, anti-fungal, inhibition of leukemia cells and as an anti-tumor agent (See Table 2). These data support the claim that the breadfruit tree may be an effective medicine with the potential to treat an assortment of medical conditions. Although some ethnobotanical information regarding traditional alternative uses of breadfruit exists (Navarro et al. 2007, Ragone 1997), the literature is vague regarding methods of preparation, the degree of cultivar specificity, and other details that may be required in order to successfully identify useful products/compounds.

Table 2. Identity and reported biological activity of compounds previously from breadfruit (Artocarpus altilis (Parkinson) Fosberg). Compound identities are presented as they appear in the original publications and may not comply with IUPAC principles of chemical nomenclature.

\begin{tabular}{|l|l|l|l|}
\hline Compound & Plant Part & Reported Biological Activity & Reference \\
\hline 1,2-cyclohexanediol & Fruit (fresh and cooked) & & Iwaoka et al. 1994 \\
\hline 1-methylbutyl acetate & Fruit (cooked) & & Iwaoka et al. 1994 \\
\hline 1-octen-3-01 & Fruit (fresh and cooked) & & Iwaoka et al. 1994 \\
\hline 1-penten-3-01 & Fruit (fresh and cooked) & & Iwaoka et al. 1994 \\
\hline 2,3-butanediol & Fruit (fresh and cooked) & & Iwaoka et al. 1994 \\
\hline $\begin{array}{l}\text { 20,40,5,7-tetrahydroxy-6-(3- } \\
\text { methyl-2-butenyl)flavone }\end{array}$ & Fruit & & Iwaoka et al. 1994 \\
\hline 2-butanone & Fruit (fresh) & & Iwaoka et al. 1994 \\
\hline 2-cyclohexenol & Fruit (cooked) & Iwaoka et al. 1994 \\
\hline 2-cyclohexenone & Fruit (fresh and cooked) & & Iwaoka et al. 1994 \\
\hline
\end{tabular}




\begin{tabular}{|c|c|c|c|}
\hline Compound & Plant Part & Reported Biological Activity & Reference \\
\hline 2-ethenyl-2-butenal (tentative) & Fruit (cooked) & & Iwaoka et al. 1994 \\
\hline $\begin{array}{l}\text { 2-geranyl-2',3,4,4'- } \\
\text { hydroxydihydrochalcone }\end{array}$ & Heart Wood & 5a-Reductase inhibition & Shimizu et al. 2000 \\
\hline 2-heptanol & Fruit (fresh and cooked) & & Iwaoka et al. 1994 \\
\hline 2-heptanone & Fruit (fresh and cooked) & & Iwaoka et al. 1994 \\
\hline 2-methyl-4-pentenal & Fruit (fresh) & & Iwaoka et al. 1994 \\
\hline 2-methylbutyric acid & Fruit (fresh) & & Iwaoka et al. 1994 \\
\hline 2-pentanol & Fruit (fresh) & & Iwaoka et al. 1994 \\
\hline 2-pentanone & Fruit (fresh) & & Iwaoka et al. 1994 \\
\hline 3-cyclohexenol & Fruit (cooked) & & Iwaoka et al. 1994 \\
\hline 3-hexene-2,5-diol (tentative) & Fruit (cooked) & & Iwaoka et al. 1994 \\
\hline 3-hexene-2,5-diol (tentative) & Fruit (cooked) & & Iwaoka et al. 1994 \\
\hline 3-hydroxy-2-butanone & Fruit (fresh and cooked) & & Iwaoka et al. 1994 \\
\hline $3 \beta$-acetoxyolean-12-en-11-one & Fruit & & $\begin{array}{l}\text { Amarasinghe } \\
\text { et al. } 2008\end{array}$ \\
\hline 5-ethyl2(5H)-furanone & Fruit (fresh and cooked) & & Iwaoka et al. 1994 \\
\hline AC-3-1 & Inflorescence & & Nomura et al. 1998 \\
\hline AC-3-2 & Inflorescence & & Nomura et al. 1998 \\
\hline AC-3-3 & Inflorescence & & Nomura et al. 1998 \\
\hline AC-5-1 & Inflorescence & & Nomura et al. 1998 \\
\hline AC-5-2 & Inflorescence & & Nomura et al. 1998 \\
\hline Amyl alcohol & Fruit (cooked) & & Iwaoka et al. 1994 \\
\hline Artocarpin & Unspecified & & Hakim et al. 2006 \\
\hline $\begin{array}{l}\text { Artocarpin dichoromethane } \\
\text { hemisolvate }\end{array}$ & Root Bark & & $\begin{array}{l}\text { Chantrapromma } \\
\text { et al. } 2007\end{array}$ \\
\hline Artochamins B & Root Cortex & Anti-platelet & Wang et al. 2006 \\
\hline Artochamins D & Root Cortex & Anti-platelet & Wang et al. 2006 \\
\hline Artocommunol CC & Root Cortex & & Wang et al. 2006 \\
\hline Artoindonesianin B & Unspecified & & Hakim et al. 2006 \\
\hline Artoindonesianin $\mathrm{F}$ & Unspecified & & Hakim et al. 2006 \\
\hline Artomunoflavonone & Root Cortex & & Wang et al. 2006 \\
\hline Artomunoisoxanthone & Root Cortex & & Wang et al. 2006 \\
\hline Artomunoxanthentrione & Root Bark & & Nomura et al. 1998 \\
\hline Artomunoxanthone & Root Bark & & Nomura et al. 1998 \\
\hline Artomunoxanthotrione epoxide & Root Bark & & Nomura et al. 1998 \\
\hline Artonin E & Unspecified & $\begin{array}{l}\text { Arachidonate 5-lipoxygenase } \\
\text { inhibition; Inhibit leukemia cells }\end{array}$ & Nomura et al. 1998 \\
\hline Artonin $\mathrm{E}$ & Unspecified & & Hakim et al. 2006 \\
\hline Artonin $\mathrm{F}$ & Unspecified & & Nomura et al. 1998 \\
\hline artonin V & Stem Bark & & Nomura et al. 1998 \\
\hline Artonol A & Unspecified & & Nomura et al. 1998 \\
\hline Artonol B & Unspecified & & Nomura et al. 1998 \\
\hline Artonol B & Unspecified & & Hakim et al. 2006 \\
\hline
\end{tabular}



security and novel foods in the $21^{\text {st }}$ Century

\begin{tabular}{|c|c|c|c|}
\hline Compound & Plant Part & Reported Biological Activity & Reference \\
\hline Artonol C & Unspecified & & Nomura et al. 1998 \\
\hline Artonol D & Unspecified & & Nomura et al. 1998 \\
\hline Artonol E & Unspecified & & Nomura et al. 1998 \\
\hline Benzaldehyde & Fruit (cooked) & & Iwaoka et al. 1994 \\
\hline Benzyl acetate & Fruit (cooked) & & Iwaoka et al. 1994 \\
\hline Benzyl alcohol & Fruit (fresh and cooked) & & Iwaoka et al. 1994 \\
\hline Butanol & Fruit (fresh and cooked) & & Iwaoka et al. 1994 \\
\hline Butyric acid & Fruit (fresh) & & Iwaoka et al. 1994 \\
\hline Chaplasin & Unspecified & & Hakim et al. 2006 \\
\hline Chloroform & Fruit (fresh and cooked) & & Iwaoka et al. 1994 \\
\hline Cinnamic alcohol & Fruit (fresh and cooked) & & Iwaoka et al. 1994 \\
\hline Cis-2-hexenal & Fruit (cooked) & & Iwaoka et al. 1994 \\
\hline Cis-3-hexenol & Fruit (fresh and cooked) & & Iwaoka et al. 1994 \\
\hline Cis-3-hexenyl acetate & Fruit (fresh and cooked) & & Iwaoka et al. 1994 \\
\hline Cycloaltilisin & Stem & & Chen et al. 1993 \\
\hline Cycloaltilisin 6 & Inflorescence Stipule & & Patil et al. 2002 \\
\hline Cycloartenyl acetate & Fruit & & \begin{tabular}{|l|} 
Amarasinghe \\
et al. 2008 \\
\end{tabular} \\
\hline Cycloartobiloxanthone & Unspecified & & Hakim et al. 2006 \\
\hline Cycloartocarpin & Unspecified & & Hakim et al. 2006 \\
\hline Cycloartomunin & Root Bark & & Nomura et al. 1998 \\
\hline Cycloartomunoxanthone & Root Bark & & Nomura et al. 1998 \\
\hline Cyclocommunin & Root Bark & & Nomura et al. 1998 \\
\hline Cyclocommunol & Root Bark & & Nomura et al. 1998 \\
\hline Cyclocomunomethonol & Root Cortex & & Wang et al. 2006 \\
\hline Cyclohexyl benzene & Fruit (fresh) & & Iwaoka et al. 1994 \\
\hline Cyclomorusin & Unspecified & & Nomura et al. 1998 \\
\hline Cyclomulberrin & Unspecified & & Nomura et al. 1998 \\
\hline Cyclopentanol & Fruit (fresh and cooked) & & Iwaoka et al. 1994 \\
\hline Cyclyaltilisin 7 & Inflorescence Stipule & & Patil et al. 2002 \\
\hline $\begin{array}{l}\text { Diethylene glycol } \\
\text { monoethyl ether }\end{array}$ & Fruit (fresh and cooked) & & Iwaoka et al. 1994 \\
\hline Dihydroartomunoxanthone & Root Cortex & Anti-platelet & Wang et al. 2006 \\
\hline Dihydrocycloartomunin & Root Bark & & Nomura et al. 1998 \\
\hline Dihydroisocycloartomunin & Root Bark & & Nomura et al. 1998 \\
\hline Dimethylbenzenepropionic acid & Fruit (cooked) & & Iwaoka et al. 1994 \\
\hline Engeletin & Unspecified & & Nomura et al. 1998 \\
\hline Ethanol & Fruit (cooked) & & Iwaoka et al. 1994 \\
\hline Ethyl 3-hydroxybutyrate & Fruit (fresh and cooked) & & Iwaoka et al. 1994 \\
\hline Ethyl acetate & Fruit (cooked) & & Iwaoka et al. 1994 \\
\hline Ethyl benzoate & Fruit (cooked) & & Iwaoka et al. 1994 \\
\hline Ethyl butyrate & Fruit (fresh) & & Iwaoka et al. 1994 \\
\hline Ethyl palmitate & Fruit (fresh) & & Iwaoka et al. 1994 \\
\hline
\end{tabular}




\begin{tabular}{|c|c|c|c|}
\hline Compound & Plant Part & Reported Biological Activity & Reference \\
\hline Friedelan-3-ol & Root Bark & & Fun et al. 2007 \\
\hline Friedelin & Root Bark & & Fun et al. 2007 \\
\hline Frutackin & Seeds & Chitin binding, anti-fungal & Trindade et al. 2006 \\
\hline $\begin{array}{l}\text { Geranyl dihydrochalcones } \\
\text { (9 structures) }\end{array}$ & Leaves & & Wang et al. 2008 \\
\hline Hexanal & Fruit (fresh and cooked) & & Iwaoka et al. 1994 \\
\hline Hexanoic acid & Fruit (fresh and cooked) & & Iwaoka et al. 1994 \\
\hline Hexanol & Fruit (fresh and cooked) & & Iwaoka et al. 1994 \\
\hline Hexyl acetate & Fruit (fresh and cooked) & & Iwaoka et al. 1994 \\
\hline Isoamyl alcohol & Fruit (fresh and cooked) & & Iwaoka et al. 1994 \\
\hline Isoartocarpesin & Fruit & & $\begin{array}{l}\text { Amarasinghe } \\
\text { et al. } 2008\end{array}$ \\
\hline Isocyclomorusin & Stem & & Chen et al. 1993 \\
\hline Isocyclomuberrin & Stem & & Chen et al. 1993 \\
\hline KB-2 & Stem Bark & Inhibit leukemia cells & Nomura et al. 1998 \\
\hline Methyl acetate & Fruit (cooked) & & Iwaoka et al. 1994 \\
\hline Moracin M & Fruit & $\begin{array}{l}\text { Anti-fungal; anti-oxidant; } \\
\text { cytotoxic; phytotoxic }\end{array}$ & $\begin{array}{l}\text { Amarasinghe } \\
\text { et al. } 2008\end{array}$ \\
\hline Morusin & Stem Bark & Anti-tumour & $\begin{array}{l}\text { Nomura et al. 1998; } \\
\text { Hakim et al. } 2006\end{array}$ \\
\hline Norartocarpanone & Fruit & & $\begin{array}{l}\text { Amarasinghe } \\
\text { et al. } 2008\end{array}$ \\
\hline Norartocarpetin & Fruit & & $\begin{array}{l}\text { Amarasinghe } \\
\text { et al. } 2008\end{array}$ \\
\hline Octanoic acid & Fruit (fresh and cooked) & & Iwaoka et al. 1994 \\
\hline Oxyresveratrol & Fruit & Anti-fungal; anti-oxidant & $\begin{array}{l}\text { Amarasinghe } \\
\text { et al. } 2008\end{array}$ \\
\hline Phenylpropyl alcohol & Fruit (fresh and cooked) & & Iwaoka et al. 1994 \\
\hline Prenylflavanoids (3 structures) & Unspecified & & Lu et al. 2007 \\
\hline Sitosterol & Fruit & & $\begin{array}{l}\text { Amarasinghe } \\
\text { et al. } 2008\end{array}$ \\
\hline Sitosterol b-D-glucopyranoside & Fruit & & $\begin{array}{l}\text { Amarasinghe } \\
\text { et al. } 2008\end{array}$ \\
\hline Toluene & Fruit (cooked) & & Iwaoka et al. 1994 \\
\hline Trans,trans-2,4-heptadienal & Fruit (fresh) & & Iwaoka et al. 1994 \\
\hline $\begin{array}{l}\text { Trans-2(or } \\
\text { 4)-chlorocyclohexano1 }\end{array}$ & Fruit (fresh and cooked) & & Iwaoka et al. 1994 \\
\hline Trans-2-hexenal & Fruit (cooked) & & Iwaoka et al. 1994 \\
\hline Trans-2-hexenol & Fruit (fresh and cooked) & & Iwaoka et al. 1994 \\
\hline Trans-2-pentenal & Fruit (fresh and cooked) & & Iwaoka et al. 1994 \\
\hline Trans-3-hexenoic acid & Fruit (fresh) & & Iwaoka et al. 1994 \\
\hline Trans-3-hexenol & Fruit (fresh and cooked) & & Iwaoka et al. 1994 \\
\hline Vanillin & Fruit (cooked) & & Iwaoka et al. 1994 \\
\hline$y$ - hexalactone & Fruit (cooked) & & Iwaoka et al. 1994 \\
\hline y-valerolactone & Fruit (fresh and cooked) & & Iwaoka et al. 1994 \\
\hline
\end{tabular}




\section{Jones et al. - Beyond the Bounty: Breadfruit (Artocarpus altilis) for food security and novel foods in the $21^{\text {st }}$ Century}

\section{Nutritional Composition}

Breadfruit is most often eaten as a staple food due to the high level of carbohydrates found in the flesh of the fruit (Figure 2A; Morton 1987, Ragone 1997, Ragone \& Cavaletto 2006, Wootton \& Tumalii 1984). In addition to being a valuable source of carbohydrates, breadfruit is also high in fiber, some vitamins and minerals. The nutrient composition of breadfruit reported in the literature is highly variable and extensive studies of the many existing cultivars have not been conducted. For example, the reported protein content of the fresh fruit varies by almost four-fold, reported fat content varies by more than a factor of 20 , and a similar trend is seen in most of the micronutrients (Table 3). This extreme variation in nutritional content may be a result of differences in the maturity of the fruit tested, production systems, environmental factors, inconsistent analytical methods, and cultivars tested (Englberger et al. 2003, Ragone \& Cavaletto 2006, Wootton \& Tumaalii 1984). There is a need to conduct a comprehensive survey of representative cultivars in a controlled manner to determine the degree of variability among cultivars and identify elite genotypes.
Breadfruit is most often consumed fresh, used as a starchy vegetable. One of the biggest limiting factors for large scale production and international trade is the perishable nature of the fruit. In typical conditions, the fruit will begin to deteriorate in approximately five days (Worrell et al. 2002). The shelf life of breadfruit can be extended up to 3-4 weeks using controlled atmosphere storage maintained at $16^{\circ} \mathrm{C}$ with $5 \%$ oxygen, $5 \%$ carbon dioxide (Sankat \& Maharaj 2007). The use of controlled atmosphere storage has significant potential to aid in scaling up breadfruit production and export, but these facilities are currently not available to growers in many regions that cultivate the crop. Traditionally, many Oceanic societies preserve breadfruit through a process of pit fermentation (Atchley \& Cox 1985); however, this has not spread into new areas and may not be readily incorporated into diverse international diets.

In order to increase the shelf-life of breadfruit and create a product that can be incorporated into a variety of diets, the production of flour is an ideal approach. Breadfruit flour has been successfully used in stiff porridges (Mayaki et al. 2003), infant formulas (Esparagoza \& Tangonan 1993), extruded products (McHugh et al. 2007), bread (Ayodele \& Oginni 2002, Esuoso \& Bamiro 1995,

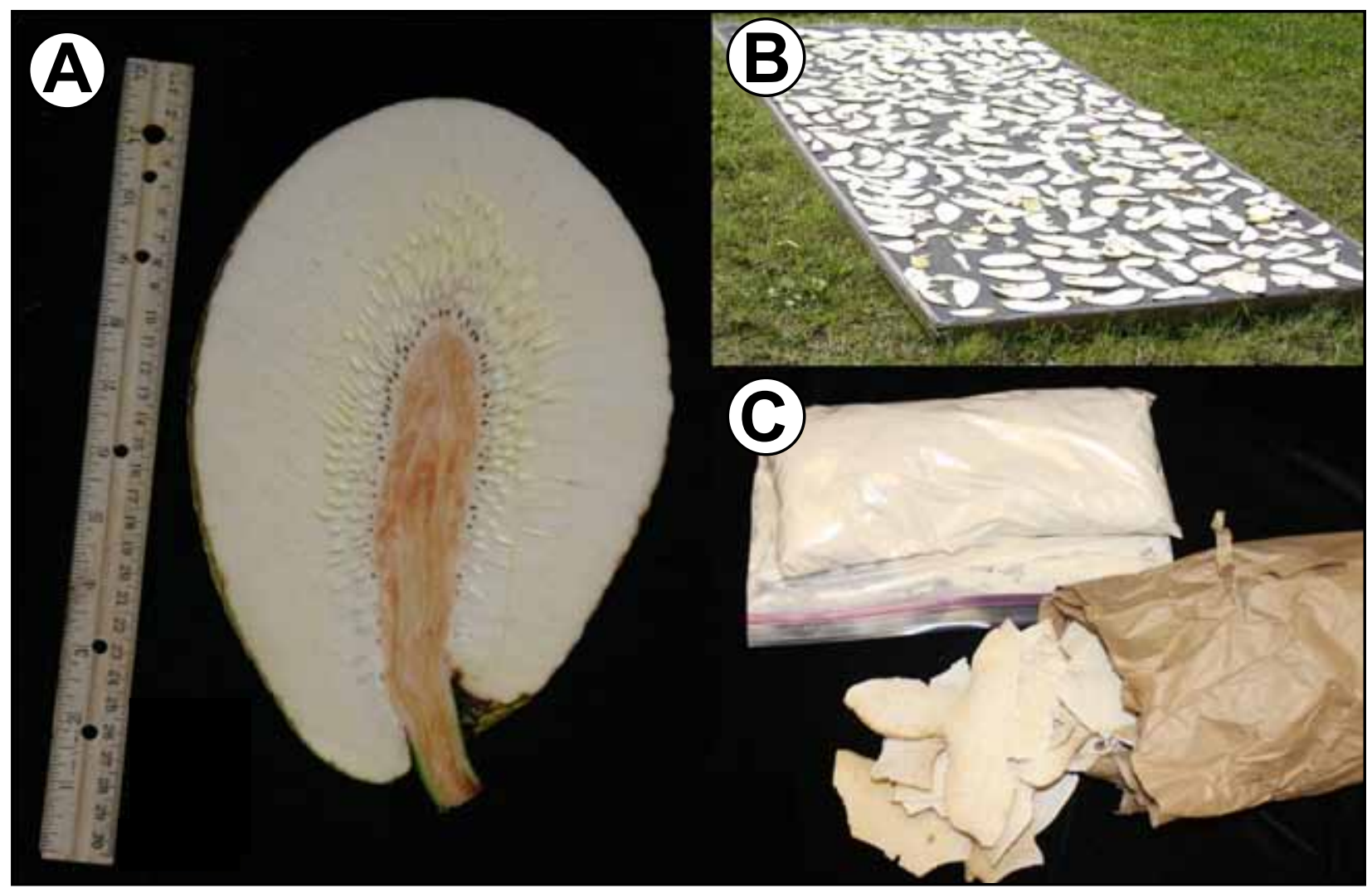

Figure 2. Preparation of flour from breadfruit (Artocarpus altilis (Parkinson) Fosberg). A. Mature fruit are peeled, halved and cored prior to slicing. B. Slices are dried on simple wire racks in sunlight or under a roof until fully dehydrated $\mathbf{C}$. Dry slices can be ground into a fine powder using a variety of mills and burr grinders. 
Table 3. Reported nutrient composition of breadfruit (Artocarpus altilis (Parkinson) Fosberg) mesocarp, mesocarp flour, fresh seed, and seed flour. ND = Not Detected, - = Not reported. Data compiled from (Englberger et al. 2003, Englberger et al. 2007, Huang et al. 2000, Mayaki et al. 2003, Morton 1987, Oshodi et al. 1999, Ragone 1997, Ragone \& Cavaletto 2006, Webster 2006, Wootton \& Tumaalii 1984).

\begin{tabular}{|c|c|c|c|c|c|c|c|c|}
\hline & \multicolumn{2}{|c|}{ Fresh Fruit } & \multicolumn{2}{|c|}{ Breadfruit Flour } & \multicolumn{2}{|c|}{ Fresh Seeds } & \multicolumn{2}{|c|}{$\begin{array}{l}\text { Seed Flour } \\
\text { (Dry/Flour) }\end{array}$} \\
\hline & Min & Max & Min & Max & Min & Max & Min & Max \\
\hline Moisture content (\%) & 62.7 & 89.16 & 2.55 & 21.02 & 35.08 & 61.9 & 8 & 8 \\
\hline kcal (per 100g) & 105 & 138 & - & - & - & - & - & - \\
\hline Protein (\%) & 0.6 & 2.24 & 2.9 & 6.6 & 5.25 & 13.3 & 13.8 & 19.96 \\
\hline Fat (\%) & 0.1 & 2.36 & 1.8 & 2.8 & 2.5 & 5.59 & 3 & 12.79 \\
\hline Carbohydrates (\%) & 21.5 & 33 & 66.6 & 77.3 & 26.6 & 44.03 & 15.95 & 64.5 \\
\hline Starch (\%) & 20.1 & 20.1 & 53.4 & 75.7 & - & - & - & - \\
\hline Sugars (\%) & 2.9 & 2.9 & 2.17 & 31.8 & - & - & - & - \\
\hline Total fiber (\%) & 0.9 & 7.37 & 2.84 & 10.7 & 1.34 & 2.14 & 1.7 & 3.87 \\
\hline Soluble fiber (\%) & ND & 2.81 & - & - & - & - & - & - \\
\hline \multicolumn{9}{|l|}{ Minerals } \\
\hline Ash (\%) & 0.56 & 1.2 & 1.69 & 4.5 & 1.5 & 5.58 & 3.42 & 3.5 \\
\hline Sodium (mg/100g) & 1 & 70 & - & - & ND & ND & 0.29 & 0.29 \\
\hline Magnesium (mg/100g) & 20 & 34 & - & - & ND & ND & 0.08 & 0.08 \\
\hline Phosphorous (mg/100g) & 0.04 & 79 & - & - & 0.35 & 189 & 0.16 & 0.37 \\
\hline Potassium (mg/100g) & 283 & 480 & - & - & - & - & 0.7 & 0.7 \\
\hline Calcium (mg/100g) & 0.05 & 30 & - & - & 0.11 & 48.3 & 0.12 & 0.18 \\
\hline Iron (mg/100g) & 0.29 & 2.4 & - & - & 2.3 & 3.87 & - & - \\
\hline Copper (mg/100g) & 0.08 & 0.08 & - & - & - & - & - & - \\
\hline Boron (mg/100g) & 0.52 & 0.52 & - & - & - & - & - & - \\
\hline Zinc (mg/100g) & 0.07 & 0.13 & - & - & - & - & - & - \\
\hline \multicolumn{9}{|l|}{ Vitamins } \\
\hline Vitamin B1 (mg/100g) & 0.09 & 0.15 & - & - & - & - & - & - \\
\hline Vitamin B2 (mg/100g) & 0.02 & 0.05 & - & - & - & - & - & - \\
\hline Vitamin B3 $(\mathrm{mg} / 100 \mathrm{~g})$ & 0.75 & 1.4 & - & - & - & - & - & - \\
\hline Vitamin C (mg/100g) & 1.6 & 34.4 & - & - & 1.9 & 22.6 & - & - \\
\hline$\beta$-carotene $(\mu \mathrm{g} / 100 \mathrm{~g})$ & ND & 19.8 & - & - & - & - & - & - \\
\hline Retinol equivalents $(\mu \mathrm{g} / 100 \mathrm{~g})$ & ND & 157 & - & - & - & - & - & L \\
\hline Lutein $(\mu \mathrm{g} / 100 \mathrm{~g})$ & 38.6 & 119.7 & - & - & - & - & - & - \\
\hline Thiamin (mg/100g) & 0.07 & 0.28 & - & - & 0.13 & 0.33 & 0.18 & 0.18 \\
\hline Riboflavin (mg/100g) & 0.03 & 0.1 & - & - & 0.08 & 0.1 & 0.84 & 0.84 \\
\hline Niacin (mg/100g) & 0.5 & 1.96 & - & - & 1.8 & 3.54 & 2.6 & 2.6 \\
\hline
\end{tabular}

Nochera \& Caldwell 1992), cake (Ayodele \& Oginni 2002), pancakes (Ayodele \& Oginni 2002) and biscuits (Nnam \& Nwokocha, 2003, Olaoye et al. 2007, Omobuwajo 2003). For some items such as infant formulas, stiff porridges and extruded products, breadfruit flour was found to be ideal, and produced a high quality product (Esparagoza \& Tangonan 1993, Mayaki et al. 2003, McHugh et al. 2007). In products where breadfruit was used in place of wheat flour, the quality of the products often suffers when a high proportion of breadfruit flour is used. This effect is most pronounced in traditional leavened wheat breads where products containing more than $10 \%$ breadfruit flour suffer from cracking and crumbling, but in some studies was still acceptable at rates of up to $30 \%$ (Ayodele \& Oginni 2002, Esuoso \& Bamiro 1995, Nochera \& Caldwell 1992). In the production of biscuits, a higher level of breadfruit flour 


\section{Jones et al. - Beyond the Bounty: Breadfruit (Artocarpus altilis) for food security and novel foods in the $21^{\text {st }}$ Century \\ could be used, up to $67 \%$, before product quality suffered \\ Agronomic Considerations} (Nnam \& Nwokocha 2003, Olaoye et al. 2007, Omobuwajo 2003). The differential performance of breadfruit flour relative to wheat flour is likely due to the intrinsic differences in their chemical and physical properties. In comparison to wheat flour, breadfruit flour is relatively high in total ash and crude fiber, but low in protein (Esuoso \& Bamiro 1995, Olaoye et al. 2007). The relative mineral and vitamin profile is difficult to ascertain due to the high level of variation observed, and is likely dependent upon the cultivar used in the flour preparation. Although the bulk of research has been conducted on flour produced entirely from the fruit's flesh, the peel and core can be included during processing. Flour produced from whole fruit is higher in ash, fiber, protein, and has a higher bulk density than flour produced from just the fruit flesh (Adewusi et al. 1995, Mayaki et al. 2003). These differences are analogous to the production of whole wheat vs. refined wheat flours, and they may both find applications in the future.

Breadfruit has also been investigated as an alternative source of starch for industrial and pharmaceutical purposes. Seedless breadfruit cultivated in Venezuela yielded $18.5 \mathrm{~g} / 100 \mathrm{~g}$ (DW) of starch (Rincón \& Padilla 2004). The breadfruit starch exhibited higher levels of water absorption, solubility and swelling power than starch obtained from corn (Zea mays L.) or amaranth (Amaranthus cruentus L.). The gelatinization temperature of the starch was $73.3^{\circ} \mathrm{C}$, and it was highly stable during heating and cooling cycles. Modification of the starch using oxidation, acetylation, annealing, or heat-moisture treatments can be used to alter some of these functional properties (Adebowale et al. 2005). In general, these modifications resulted in reduced gelling activity, solubility, pasting temperature, peak viscosity, hot paste viscosity and cold paste viscosity. Starch extracted from breadfruit has shown promising results in the pharmaceutical industry as an alternative to corn starch as a tablet binder (Adebayo \& Itiola 2003) and tablet disintegrant (Adebayo et al. 2008). Breadfruit provides a ready alternative source of starch for a variety of industrial and pharmaceutical applications.

In addition to the starchy flesh, some cultivars also produce edible seeds. This is especially significant in breadnut $(A$. camansi), where the seed accounts for the bulk of the fruit and is the most commonly ingested portion. The breadnut seed is fairly high in carbohydrates, but contains significantly higher levels of fat and protein than breadfruit flesh (Table 2-1). Breadnut can also be used to produce flour, resulting in a product rich in protein, similar or higher than that found in wheat (Esuoso \& Bamiro 1995; Oshodi et al. 1999). However, very few accessions have been studied to date and more work is required to evaluate the potential of the breadnut as a food resource (Ragone 1997).

\section{Plant Propagation}

Although some cultivars of breadfruit produce viable seeds, they do not survive desiccation and cannot be stored for long periods of time (Rowe-Dutton 1976, Zerega et al. 2004). Additionally, breadfruit is an out-crossing species and seeds do not grow true to type making seed propagation an undesirable method of propagation when a specific cultivar is desired (Ragone 2007). Traditionally, breadfruit is clonally propagated using root suckers, root cuttings, or air layering (Ragone 1997, 2006a). These methods are suitable for small scale local production, but are insufficient to meet the current global demand for planting material (Moustache \& Moustache 2007, Roberts-Nkrumah 2007). Further, shipment of root cuttings between countries is not always practical as roots can carry fungi and bacteria that spread disease and specialized agricultural permits are often required, for example, breadfruit plants being imported into the U.S.A., Fiji, and Canada must be bare root, accompanied by a phytosanitary certificate and imported to a facility holding a valid Plant Protection permit. Many of the plants do not survive this type of shipment and losses of breadfruit propagules in this cross-border process are about $60 \%$ (Murch et al. 2008). As a result, the limited amount of modern distribution of breadfruit throughout the world that exists is a slow and cumbersome process.

Large-scale mass propagation using plant tissue culture provides an alternative method for the rapid, large-scale production of breadfruit plants in a sterile controlled environment (Figure 3; Murch et al. 2007, 2008). In brief, shoot tips and other small buds (Figure $3 \mathrm{~A}$ ) are surface sterilized to remove any fungi and bacteria (Figure $3 B$ ) before being cultured in a complete medium containing sugars, vitamins, minerals and a gelling agent (Figure $3 \mathrm{C}$ ). Optimization of the type and concentration of plant growth regulators in the media induces the proliferation of shoots (Figure 3D) or roots (Figure 3E). Plantlets are subcultured into temporary immersion bioreactor vessels (Figure 3F) for the growth of entire plants about $10 \mathrm{~cm}$ tall in a sterile, controlled environment in about 6-8 weeks. These plantlets can then be shipped to destinations around the world or acclimatized to a soil environment for planting (Figure $3 G$ ). This process allows for production of thousands of plants that are almost identical clones of the original tree (Figure $3 \mathrm{H}, \mathrm{I}$ ). The sterile nature of this technique ensures that resulting propagules are free from insects and disease, reducing the risk to the grower, importation restrictions, and often eliminating the need for quarantine.

\section{Acclimatization and Cultivation of Trees}

Breadfruit cultivation is a time-honored tradition in much of Oceania. Young breadfruit trees are traditionally planted in small pits supplemented with compost; no further 


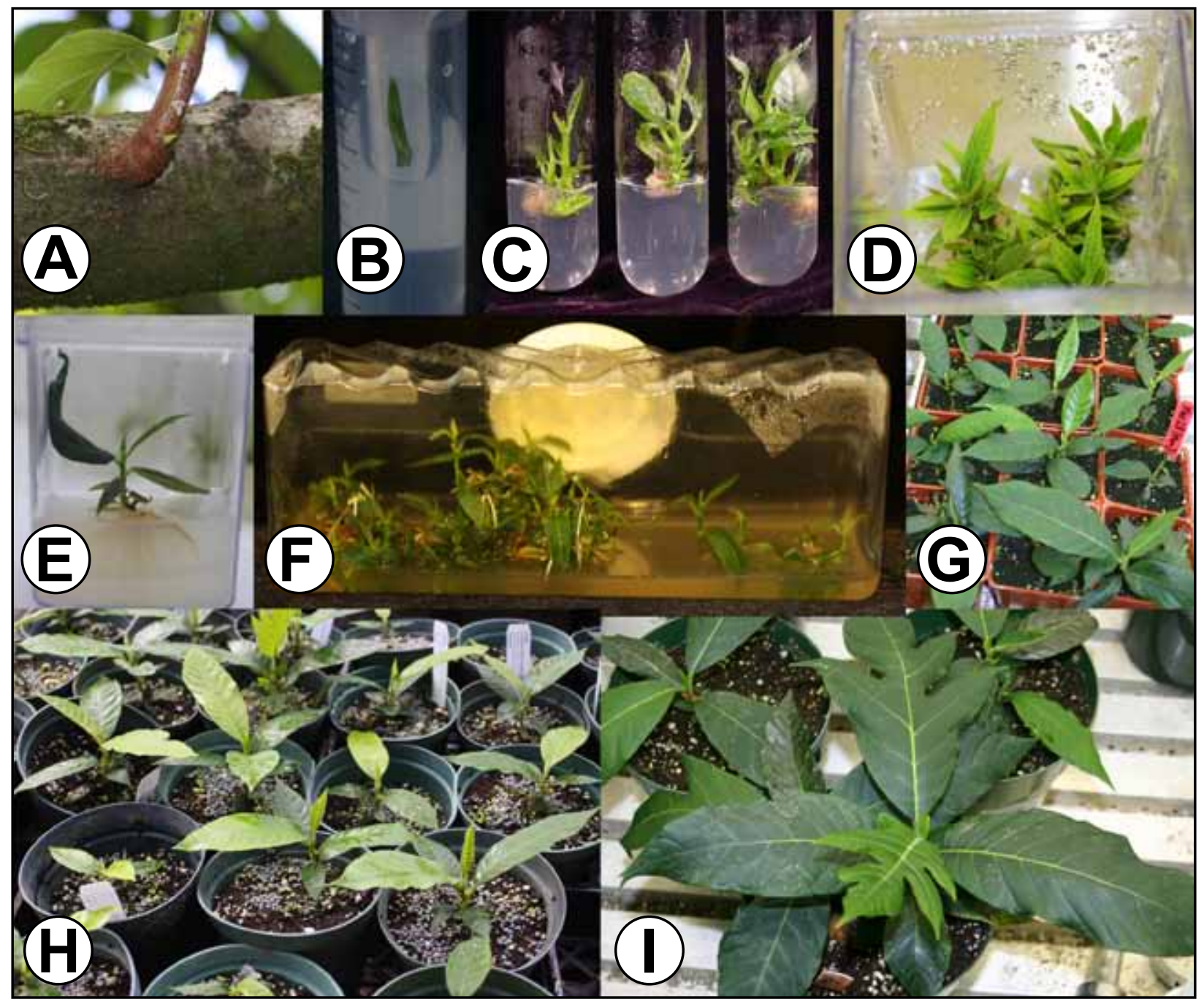

Figure 3. In-vitro production of breadfruit (Artocarpus altilis (Parkinson) Fosberg). A. Young buds from branches of mature trees provide the source materials for regeneration in tissue culture. B. Buds are disinfected of bacteria, fungi and other contaminants prior to culture onto a sterile media containing sugar, vitamins, minerals, a protein gelling agent and optimized concentrations of plant hormones. C Within $4-6$ weeks, multiple shoots develop on each of the sterile buds. D. Shoot proliferation continues for 3-4 months leading to a population of clones of the original plant in sterile tissue culture. E. Individual shoots are subcultured onto a rooting medium for development of roots and whole plants. $\mathbf{F}$. Rooted plants can be grown to a height of 3-4 inches in sterile, controlled environment bioreactors. G-I. In-vitro-grown plants can be transferred to a growth cabinet or acclimatized in a greenhouse for production of mature plants suitable for distribution and planting the natural environment.

fertilization is used (Ragone 1997). They are planted during the rainy season to ensure adequate water for successful establishment. Breadfruit trees are a key component of various low input agroforestry systems (Elevitch \& Wilkinson 2000, Raynor \& Fownes 1991). Coconut trees are often used as the upper canopy, breadfruit trees are found in the lower canopy and smaller shrubs and herbaceous crops comprise the understory (Mueller-Dombois \& Fosberg 1998). In other agroforestry systems, breadfruit is used as the upper canopy, with smaller crops grown underneath. Trees grown in agroforestry systems are generally spaced relatively far apart to accommodate the under- story crops, which results in a lower yield than would be obtained using an intensive monoculture production system (Elevitch \& Wilkinson 2000). Breadfruit grown in such a setting in Pohnpei produces yields in the range of 6.67 $\mathrm{t} /$ ha of fresh fruit (Raynor \& Fownes 1991). Depending on the cultivar used and environmental conditions this would translate to approximately $0.5-1.9 \mathrm{t} / \mathrm{ha}$ of dried fruit flesh. The lower yield obtained in a mixed cropping system is compensated for by the additional harvest of spices, essential oil plants, fruit, roots/tubers, vegetables, herbs, coffee or other commodities grown in the understory. Understory crops, specifically annual and short lived peren- 


\section{Jones et al. - Beyond the Bounty: Breadfruit (Artocarpus altilis) for food security and novel foods in the $21^{\text {st }}$ Century}

nials, are especially useful during the early establishment phase to provide income and/or food before the tree begins to bear fruit. Agroforestry also diversifies production and reduces the risk of catastrophic losses due to diseases or natural disasters that kill the tree crop. Breadfruit trees are also commonly found as "backyard trees" growing in the gardens of individual residences (Gbehounou 2007).

\section{Modern Breadfruit Production}

For better or worse, modern agriculture has shifted primarily to monoculture production systems. Although breadfruit is a major staple crop in many countries, large scale cultivation is virtually non-existent. The majority of breadfruit is still obtained from small growers, and consumed locally. Very little breadfruit is exported, with the Caribbean being a primary source, exporting around 1500 tons/year (Roberts-Nkrumah 2007). Some of the primary factors preventing large-scale production of breadfruit are the highly perishable nature of the fruit, lack of planting material, and a lack of marketing and distribution networks (Roberts-Nkrumah 2007).

Information on optimal fertilization regimes, pruning/training, planting density and other practices for modern orchard production have not been extensively evaluated, but there is some preliminary information (Coronel 1990, Goebel 2007, Lebegin et al. 2007, Webster 2006). Soil tillage, specifically deep tilling, has been conducted prior to orchard establishment (Lebegin et al. 2007). However, this is not traditionally required and may not be necessary in all locations and soil types. Likewise, fertilizer has been applied, but the nutrient requirements of the tree are not well known and application of fertilizer should be conducted based on a soil nutrient analysis. Planting densities ranging from 83.3-333 trees/ha have been used but even at 83.3 trees/ha the plants were too crowded upon maturity; lower planting densities have been recommended (Goebel 2007, Lebegin et al. 2007). The practice of planting sturdy trees such as Syzygium spp., Casuarina spp., and coconuts (Cocos nucifera (L.)) at the edge of the orchard has been recommended to minimize damage caused by high winds (Goebel 2007). To date, mechanical harvesters have not been utilized for the cultivation of breadfruit and hand harvesting remains the only viable option. It is estimated that over $50 \%$ of the fruit may be lost due to the difficulty of harvesting fruit from large trees (Roberts-Nkrumah 2007).

\section{Yield Potential}

The moisture content of the fruit ranges from $62.7-89 \%$ (Table 1) and individual trees produce between 50 and 900 fruit per season depending on environmental conditions, tree size and cultivar (Lorens \& Englberger 2007, Marte 1986, Ragone 1997, 2006a). Fruit generally weigh 1-2 kg, but can reach up to $6 \mathrm{~kg}$ (Ragone 1997, 2006a,
Ragone \& Cavaletto 2006). The edible portion of the fruit accounts for approximately $70-75 \%$ of the fruit, with the skin and receptacle accounting for the remaining portion (Ragone 1997). Based on these factors the estimated yield of breadfruit ranges from $4 \mathrm{t} /$ ha to $50 \mathrm{t} /$ ha with edible dry weight yields of up to $14 \mathrm{t} / \mathrm{ha}$. Bowers (1981) reported that $6 \mathrm{t} /$ ha of edible dry matter production for breadfruit is a reasonable estimate (Sauerborn 2002). For perspective, the average global yield of irrigated modern rice is $4.1 \mathrm{t} / \mathrm{ha}$ with an estimated upper limit of approximately 10 t/ha using modern cultivars in intensive agricultural systems (Calpe 2007, FAO 1999).

\section{The Potential of Breadfruit}

Hunger is a problem that has ravaged human civilization since pre-history. With the current rate of population growth, food shortages are imminent unless dramatic increases in food production are achieved. Many of the countries that suffer from high levels of undernourishment are found in tropical climates that are suitable for breadfruit production. The significance of this is apparent when one compares the yield of breadfruit to other commonly grown staple crops such as rice, corn and wheat. Some cultivars of breadfruit also contain significant amounts of essential vitamins and minerals (Englberger et al. 2003, Ragone \& Cavaletto 2007). Breadfruit offers an opportunity to significantly increase food production in regions of the world that need it the most in a sustainable manner, and could play a substantial role in averting a crisis.

In addition to its potential in fighting hunger, breadfruit has significant economic potential worldwide once the obstacles to developing a global market are overcome. With adequate product development and marketing, processed breadfruit could have huge potential value as a grain substitute, cattle feed, latex and lumber. The global market for grain is enormous. Projections for grain consumption estimate that 2.4 billion tons of grain will be consumed by 2015 with a value of approximately $\$ 600$ billion (Bruinsma 2003). This is an average increase of 27 million tons $(\$ 7$ billion) per year. As breadfruit emerges as a substitute for grain-based foods, the value of the worldwide breadfruit crop could easily reach billions of dollars in light of these economic trends.

Even in the absence of these trends, breadfruit would have significant growth potential in developed markets. Since the nutritional value of breadfruit flour has several advantages over cereal grains, an obvious application for the processed carbohydrate is as a nutritional supplement for products designed to appeal to the growing health conscious consumer group. A specific advantage of flour produced from breadfruit is that it is gluten free, giving breadfruit flour a unique market niche for those who suffer from Celiac disease and gluten allergies which affects approximately 1 in 133 people within the U.S. (Fasano et al. 2003). The market for gluten-free products in the U.S. 
alone was approximately $\$ 700$ million in 2007 and growing with a projected value of $\$ 1.7$ billion by 2010 (Cureton 2007). Currently, gluten free products are considered expensive, presenting opportunity for gluten free flours such as breadfruit.

Breadfruit, and some of the by-products of breadfruit processing, can also be used as livestock feed (Ragone 1997). According to the National Corn Growers Association, over one half of all corn grown in the U.S. is fed to livestock within the U.S. and overseas (www.NCGA. com). With the price of corn reaching over $\$ 6$ per bushel in 2008 (Tenenbaum 2008), the economic potential for an alternative livestock feed such as breadfruit is substantial. There are several secondary and tertiary products that may eventually develop from a global breadfruit market. Although the economic potential of these products may be less obvious than using breadfruit as a food source for people or livestock, examination of these possibilities reveals the true magnitude of breadfruit's global economic potential. These products are summarized below:

1. Ethanol. Ethanol can be made from breadfruit, by-products of breadfruit flour production, or from various parts of the tree (llori et al. 1996). In 2006, approximately 40 billion liters of ethanol biofuel was produced, utilizing about $50 \%$ of Brazil's sugarcane, and $20 \%$ of the American corn harvest (World Bank 2007). The demand for ethanol biofuel is increasing, and breadfruit could provide what appears to be an economically viable alternative feedstock (llori et al. 1996).

2. Latex. Latex derived from breadfruit has many traditional applications (Ragone 1997) and could find modern uses and be sold as a by-product. Since the latex can be harvested without detriment to the tree, this is complementary to production of food products. 3. Wood. Wood from breadfruit trees has been used locally for generations (Ragone 1997). It is resistant to moisture and pests, and performs well in furniture, boats, and other applications. Although harvesting the wood obviously cannot be a primary objective since it precludes fruit production, it is a possible source of additional income for growers as trees become less productive.

4. Carbon credits. Since the Kyoto protocol of 1997 , capitalizing on carbon sequestration is as easy as selling carbon credits on the Chicago Climate Exchange (CCX), the European Climate Exchange (ECX) or the Global Carbon Exchange (GCX) (Capoor \& Ambrosi 2008). Since breadfruit trees are proficient carbon sinks, and the breadfruit farming industry will directly address the ongoing deforestation problem in tropical regions, corporations in developed nations may use breadfruit as a way to offset their carbon emissions as cap-and-trade programs gain steam. This is a growing market and has grown from a value of $\$ 10$ billion in 2005 to approximately $\$ 64$ billion in 2007 (Capoor \& Ambrosi 2008).

Overall, the economic impact of a global breadfruit market could be fundamental in helping less developed tropical nations improve their standard of living and per capita income. Currently, regions where breadfruit can be grown are among the poorest regions in the world. In addition, the tendency for these countries to import grains from developed nations like the U.S. exacerbates the cycle of poverty. By developing a global market for an environmentally sustainable crop, these regions would strengthen their positions in the global economy as well as improving economic conditions locally.

\section{Literature Cited}

Adebayo, A.S. \& Itiola, O.A. 2003. Effects of breadfruit and cocoyam starch mucilage binders on disintegration and dissolution behaviors of paracetamol tablet formulations. Pharmaceutical Technology 27(3):78-90.

Adebayo, S.A., E. Brown-Myrie \& O.A. Itiola. 2008. Comparative disintegrant activities of breadfruit starch and official corn starch. Powder Technology 181(2):98-103.

Adebowale, K.O., B.I. Olu-Owolabi, E. Olawumi \& O.S. Lawal. 2005. Functional properties of native, physically and chemically modified breadfruit (Artocarpus altilis) starch. Industrial Crops \& Products 21(3):343-351.

Adewusi, S.R.A., J. Udio \& B.A. Osuntogun. 1995. Studies on the carbohydrate content of breadfruit (Artocarpus communis Forst.) from South-Western Nigeria. StarchStärke 47(8):289-294.

Amarasinghe, N.R., L. Jayasinghe, N., Hara \& Y. Fujimoto. 2008. Chemical constituents of the fruits of Artocarpus altilis. Biochemical Systematics and Ecology 36(4):323325.

Atchley, J. \& P.A. Cox. 1985. Breadfruit fermentation in Micronesia. Economic Botany 39(3):326-335.

Ayodele, M.S. \& E.O. Oginni. 2002. Utilization of breadfruit (Artocarpus incisa) flour for confectionery products. Tropical Science 42(3):120-122.

Barrau, J. 1976. Breadfruit and relatives. Pp. 201-202 in Evolution of Crop Plants. Edited by N.W. Simmonds. Longman, London.

Beaglehole, J.C. 1962. Editor of The Endeavour Journal of Joseph Banks 1768-1771. Volumes 1-2. Trustees of the Public Library of New South Wales in association with Angus and Robertson, Sydney, Australia. 


\section{Jones et al. - Beyond the Bounty: Breadfruit (Artocarpus altilis) for food security and novel foods in the $21^{\text {st }}$ Century}

Bennett, F.D. \& C. Nozzolillo. 1987. How many seeds in a seeded breadfruit, Artocarpus altilis (Moraceae)? Economic Botany 41(3):370-374.

Bipat, R., J.R. Toelsie, R.F. Joemmanbaks, J.M. Gummels, J. Klaverweide, N. Jhanjan, S. Orie \& K. Ramjiawan. 2008. Effects of plants popularly used against hypertension on norepinephrine-stimulated guinea pig atria. Pharmacognosy Magazine 4(13):12.

Bourdy, G., P. Cabalionb, P. Amadea \& D. Laurenta. 1992. Traditional remedies used in the Western Pacific for the treatment of ciguatera poisoning. Journal of Ethnopharmacology 36:163-174.

Bourdy, G. \& A. Walter. 1992. Maternity and medicinal plants in Vanuatu. The cycle of reproduction. Journal of Ethnopharmacology 37(3):179-196.

Bowers, R.D. 1981. Breadfruit-a low energy requirement source of carbohydrate for the wet tropics. Entwicklung and Landlicher Raum 15(2):11-13.

Brantjes, N.B.M. 1981. Nectar and the pollination of bread fruit, Artocarpus altilis (Moraceae). Acta Botanica Neerlandica 30(5/6):345-352.

Bruinsma J. 2003. World Agriculture: Towards 2015/2030. An FAO perspective. Earthscan Publications, Ltd., London.

Calpe, C. 2007. Review of the rice market situation in 2007. International Rice Commission Newsletter (FAO) 56:1-24.

Capoor K. \& P. Ambrosi. 2008. State and Trends of the Carbon Market 2008. World Bank. Washington, D.C.

Chantrapromma, S., N. Boonnak, H.K. Fun \& C. Karalai. 2007. Artocarpin dichloromethane hemisolvate. Acta Crystallographica E63:1864-1866.

Chen, C.C., Y.L. Huang, J.C. Ou, C.F. Lin \& T.M. Pan. 1993. Three new prenylflavones from Artocarpus altilis. Journal of Natural Products 56(9):1594-1597.

Coenan, J. \& J. Barrau. 1961. The breadfruit tree in Micronesia. South Pacific Bulletin 11(4):37-67.

Coronel, R.E. 1990. Promising Fruits of the Philippines. University of the Philippines, Los Baños, The Philippines.

Cureton, C.R. 2007. The gluten-free diet: Can your patient afford it? Practical Gastroenterology 31(4):75-84.

Elevitch, C.R. \& K.M. Wilkinson. 2000. Agroforestry Guides for Pacific Islands. Permanent Agriculture Resources, Holualoa, Hawai i.
Englberger, L., W. Aalbersberg, P. Ravi, E. Bonnin, G.C. Marks, M.H. Fitzgerald \& J. Elymore. 2003. Further analyses on Micronesian banana, taro, breadfruit and other foods for provitamin A carotenoids and minerals. Journal of Food Composition and Analysis 16(2):219-236.

Englberger, L., G.C. Marks \& M.H. Fitzgerald. 2007. Insights on food and nutrition in the Federated States of Micronesia: A review of the literature. Public Health Nutrition 6(01):5-17.

Esparagoza, R.S. \& J.G. Tangonan. 1993. Instant baby food using banana and breadfruit flour as food base. USM $C A$ [University of Southern Mindanao College of Agriculture] Research Journal (Philippines) 4(2):175-177.

Esuoso, K.O. \& F.O. Bamiro. 1995. Studies on the baking properties of non-wheat flours-l. Breadfruit (Artocarpus artilis). International Journal of Food Sciences and Nutrition 46(3):267-273.

FAO. 1999. Production Yearbook 48, Rome, Italy. Food and Agricultural Organization, Rome.

FAO. 2007. FAO Statistical Yearbook 2004. Food and Agricultural Organization, Rome.

FAO. 2008. The State of Food Insecurity in the World 2008. Food and Agricultural Organization, Rome.

FAO. 2009a. 1.02 Billion People Hungry: One sixth of humanity undernourished-More than ever before. Food and Agriculture Organization, Rome. www.fao.org/news/ story/en/item/20568/icode/.

FAO. 2009b. The International Treaty on Plant Genetic Resources for Food and Agriculture. Food and Agricultural Organization, Rome.

FAO. 2009c. Yield Per Hectare of World Maize Crops. Food and Agricultural Organization, Rome. www.fao.org/ es/ess/chartroom/chart.asp?image=img/charts/42.gif.

FAO. 2009d. Yield Per Hectare of World Wheat Crops. Food and Agricultural Organization, Rome. www.fao.org/ es/ess/chartroom/chart.asp?image=img/charts/43.gif.

Fasano A., I. Berti, T. Gerdarduzzi, T. Not, R.B. Colletti, S. Drago, Y. Elitsur, P.H. Green, S. Guandalini, I.D. Hill, M. Pietzak, A. Ventura, M. Thorpe, D. Kryszak, F. Fornaroli, S.S. Wasserman, J.A. Murray \& K. Horvath. 2003. Prevalence of celiac disease in at-risk and not at-risk groups in the United States: A large multicenter study. Archives of Internal Medicine 163(3):286-292

Fosberg, F.R. 1941. Names in Amaranthus, Artocarpus, and Inocarpus. Journal of the Washington Academy of Sciences 31:93-96. 
Fosberg, F.R. 1960. Introgression in Artocarpus (Moraceae) in Micronesia. Brittonia 12(2):101-113.

Fownes, J.H. \& W.C. Raynor. 1993. Seasonality and yield of breadfruit cultivars in the indigenous agroforestry system of Pohnpei, Federated States of Micronesia. Tropical Agriculture 70(2):103-109.

Fun, H.K., N. Boonnak \& S. Chantrapromma. 2007. A cocrystal of friedelan-3 [beta]-ol and friedelin (0.75/0.25). Acta Crystallographica E63:2014-2016.

Gbčhounou, G. 2007. Why does Artocarpus altilis remain a backyard tree in the republic of Benin? In Proceedings of the 1st International Symposium on Breadfruit Research and Development. Acta Horticulturae 757:115-120.

Goebel, R. 2007. Breadfruit-the Australian scene. In Proceedings of the 1st International Symposium on Breadfruit Research and Development. Acta Horticulturae 757:141148.

Hakim, E.H., S.A. Achmad, L.D. Juliawaty, L. Makmur, Y.M. Syah, N. Aimi, M. Kitajima, H. Takayama \& E.L. Ghisalberti. 2006. Prenylated flavonoids and related compounds of the Indonesian Artocarpus (Moraceae). Journal of Natural Medicines 60(3):161-184.

Harvey, J. 1999. Laticifers in olona and ulu: Biological comparison and ethnobotanical significance. Journal of Young Investigators 2(1).

Heard, T.A. 1999. The role of stingless bees in crop pollination. Annual Reviews in Entomology 44(1):183-206.

Henry, T. \& J.M. Orsmond. 1928. Ancient Tahiti. Bernice P. Bishop Museum, Honolulu, Hawaii.

Huang, A., C. Titchenal \& B. Meilleur. 2000. Nutrient composition of taro corms and breadfruit. Journal of Food Composition and Analysis 13(5):859-864.

Ilori M.O., S.K. Layokun, A.O. Idowu \& O.B. Solomon. 1996. Economics of small-scale ethanol production from breadfruit and cassava via plant enzyme and acid hydrolysis. Technical QuarterlyMaster Brewer's Association of the Americas 33(1):39-43.

Iwaoka, W., Y. Hagi, K. Umano \& T. Shibamoto. 1994. Volatile chemicals identified in fresh and cooked breadfruit. Journal of Agricultural and Food Chemistry 42(4):975976.

Jarrett, F.M. 1959. Studies in Artocarpus and allied genera, III. A revision of Artocarpus subgenus Artocarpus . Journal of the Arnold Arboretum 15:298-326.
Jarrett, F.M. 1976. The syncarp of Artocarpus - A unique biological phenomenon. Gardens' Bulletin Singapore 29:35-39.

Kanzaki, S., K. Yonemori, A. Sugiura \& S. Subhadrabandhu. 1997. Phylogenetic relationships between the jackfruit, the breadfruit and nine other Artocarpus spp. from RFLP analysis of an amplified region of cpDNA. Scientia Horticulturae 70(1):57-66.

Koroveibau, D. 1967. Some Fiji Breadfruit Varieties. Fiji Department of Agriculture, Suva.

Lans, C.A. 2006. Ethnomedicines used in Trinidad and Tobago for urinary problems and diabetes mellitus. Journal of Ethnobiology and Ethnomedicine 2:45.

Lebegin, S., D. Lemerre \& F. Mademba-Sy. 2007. Horticultural evaluation of five introduced and one local breadfruit cultivar in New Caledonia. In Proceedings of the 1st International Symposium on Breadfruit Research and Development. Acta Horticulturae 757:89-92.

Lee, R.A., M.J. Balick, D.L. Ling, F. Sohl, B.J. Brosi \& W. Raynor. 2001. Cultural dynamism and change: An example from the Federated States of Micronesia. Economic Botany 55(1):9-13.

Lin, C.N., W.L. Shieh \& T.T. Jong. 1992. A pyranodihydrobenzoxanthone epoxide from Artocarpus communis. Phytochemistry 31(7):2563-2564.

Lobel, P. 1979. Folk remedies for tropical fish poisoning in the Pacific. Sea Frontiers 25:239-245.

Lorens, A. \& L. Englberger. 2007. The importance and use of breadfruit cultivars in Pohnpei, Federated States of Micronesia. In Proceedings of the 1st International Symposium on Breadfruit Research and Development. Acta Horticulturae 757:101.

Lu, Y., C. Sun, Y. Wang \& Y. Pan. 2007. Two-dimensional counter-current chromatography for the preparative separation of prenylflavonoids from Artocarpus altilis. Journal of Chromatography A 1151(1-2):31-36.

Marte, R. 1986. Nontraditional fruit crops in the Windward Islands. Proceedings Interamerican Society Tropical Horticulture 30:15-24.

Mayaki, O.M., J.O. Akingbala, G.S.H. Baccus-Taylor \& S. Thomas. 2003. Evaluation of breadfruit (Artocarpus communis) in traditional stiff porridge foods. Journal of Food, Agriculture \& Environment 1(2):54-59.

McClatchey, W.C. 1993. The Traditional Rotuman Medicinal System. Brigham Young University, Provo, Utah. 


\section{Jones et al. - Beyond the Bounty: Breadfruit (Artocarpus altilis) for food security and novel foods in the $21^{\text {st }}$ Century}

McHugh, T., Z. Pan, E. Apple \& T.A. Films. 2007. Properties of Extruded Expandable Breadfruit Products. Presented at CIGR Section VI (Postharvest Technology and Process Engineering) 3rd International Symposium: Food and Agricultural Products: Processing and Innovations, September 24-26, Naples, Italy.

Mclntoch, C. \& P. Manchew. 1993. The breadfruit in nutrition and health. Tropical Fruits Newsletter 6(5-6).

Morton, J.F. 1987. Breadfruit. Pp. 50-58 in Fruits of Warm Climates. Julia F. Morton Publisher, Miami, Florida.

Moustache, A.M. \& M. Moustache. 2007. History and use of breadfruit in the Seychelles. In Proceedings of the 1st International Symposium on Breadfruit Research and Development. Acta Horticulturae 757:135-140.

Mueller-Dombois, D. \& F.R. Fosberg. 1998. Vegetation of the Tropical Pacific Islands. Springer Verlag, Berlin.

Murch, S.J., D. Ragone, W.L. Shi, A.R. Alan \& P.K. Saxena. 2007. In vitro conservation and micropropagation of breadfruit (Artocarpus altilis, Moraceae). Pp. 279-288 in Protocols for Micropropagation of Woody Trees and Fruit. Edited by S.M. Jain \& H. Häggman. Springer, Dordrecht, The Netherlands.

Murch, S.J., D. Ragone, W.L. Shi, A.R. Alan \& P.K. Saxena. 2008. In vitro conservation and sustained production of breadfruit (Artocarpus altilis, Moraceae): modern technologies for a traditional tropical crop. Naturwissenschaften 95(2):99-107.

Navarro, M., S. Malres, J.P. Labouisse \& O. Roupsard. 2007. Vanuatu breadfruit project: Survey on botanical diversity and traditional uses of Artocarpus altilis. In Proceedings of the 1st International Symposium on Breadfruit Research and Development. Acta Horticulturae 757:8188.

Niering, W.A. 1963. Terrestrial ecology of Kapingamarangi Atoll, Caroline Islands. Ecological Monographs 33(2):131160.

Nnam, N.M. \& M.O. Nwokocha. 2003. Chemical and organoleptic evaluation of biscuits made from mixtures of hungry rice, acha (Digitaria exilis); sesame (Sesamum indicum); and breadfruit (Artocarpus altilis) flours. Plant Foods for Human Nutrition 58(3):1-11.

Nochera, C. \& M. Caldwell. 1992. Nutritional evaluation of breadfruit-containing composite flour products. Journal of Food Science 57(6):1420-1422.

Nomura, T., Y. Hano \& M. Aida. 1998. Isoprenoid-substituted flavanoids from Artocarpus plants (Moraceae). Heterocycles 47(2):1179-1205.
Olaoye, O., A. Onilude \& C. Oladoye. 2007. Breadfruit flour in biscuit making: Effects on product quality. African Journal of Food Science 1(2):20-23.

Omobuwajo, T. 2003. Compositional characteristics and sensory quality of biscuits, prawn crackers and fried chips produced from beadfruit. Innovative Food Science and Emerging Technologies 4(2):219-225.

Oshodi, A.A., K.O. Ipinmoroti \& T.N. Fagbemi. 1999. Chemical composition, amino acid analysis and functional properties of breadnut (Artocarpus altilis) flour. Nahrung 43(6):402-405.

Patil, A.D., A.J. Freyer, L. Killmer, P. Offen, P.B. Taylor, B.J. Votta \& R.K. Johnson. 2002. A new dimeric dihydrochalcone and a new prenylated flavone from the bud covers of Artocarpus altilis: Potent inhibitors of Cathepsin K. Journal of Natural Products 65(4):624-627.

Powell, D. 1977. The voyage of the plant nursery, H.M.S. Providence, 1791-1793. Economic Botany 31(4):387-431.

Ragone, D. 1991. Ethnobotany of breadfruit in Polynesia. Pp. 203-220 in Islands, Plants, and Polynesians: An Introduction to Polynesian Ethnobotany. Edited by P.A. Cox \& S.A. Banack. Dioscorides Press, Portland, Oregon.

Ragone, D. 1997. Breadfruit, Artocarpus altilis (Parkinson) Fosberg. International Plant Genetic Resources Institute, Rome.

Ragone, D. 2001. Chromosome numbers and pollen stainability of three species of Pacific Island breadfruit (Artocarpus, Moraceae). American Journal of Botany 88(4):693-696.

Ragone, D. 2006a. Artocarpus altilis (breadfruit). Pp. 85100 in Traditional Trees of of Pacific Islands: Their culture environment and use. Edited by C.R. Elevitch. Perminent Agriculture Resources, Holualoa, Hawai i.

Ragone, D. 2006b. Artocarpus camansi (Breadnut). Pp. 101-110 in Traditional Trees of of Pacific Islands: Their culture environment and use. Edited by C.R. Elevitch. Perminent Agriculture Resources, Holualoa, Hawaìi.

Ragone, D. 2007. Breadfruit: Diversity, conservation and potential. In Proceedings of the 1st International Symposium on Breadfruit Research and Development. Acta Horticulturae 757:19-30.

Ragone, D. \& C.G. Cavaletto. 2006. Sensory evaluation of fruit quality and nutritional composition of 20 breadfruit (Artocarpus, Moraceae) cultivars. Economic Botany 60(4):335-346. 
Ragone, D. \& H.I. Manner. 2006. Artocarpus mariannensis (dugdug). Pp. 127-138 in Traditional Trees of of Pacific Islands: Their culture environment and use. Edited by C.R. Elevitch. Perminent Agriculture Resources, Holualoa, Hawai i.

Ragone, D. \& W.C. Raynor. 2009. Breadfruit and its traditional cultivation and use on Pohnpei. Pp. 63-88 in Ethnobotany of Pohnpei: Plants, people, and island culture. Edited by M.J. Balick. University of Hawaii Press, Honolulu, Hawai'i and New York Botanical Garden Press, Bronx, New York.

Ragone, D., G. Tavana, J. Stevens, P. Stewart, R. Stone, P. Cox \& P. Cox. 2004. Nomenclature of breadfruit cultivars in Samoa: Saliency, ambiguity, and monomiality. Journal of Ethnobiology 24(1):33-50.

Raynor, W.C. \& J.H. Fownes. 1991. Indigenous agroforestry of Pohnpei. Agroforestry Systems 16(2):139-157.

Reeve, R.M. 1974. Histological structure and commercial dehydration potential of breadfruit. Economic Botany 28(1):82-96.

Rincón, A.M. \& F.C. Padilla. 2004. Physicochemical properties of breadfruit (Artocarpus altilis) starch from Margarita island, Venezuela. Archivos Latinoamericanos de Nutricion 54(4):449-456.

Roberts-Nkrumah, L.B. 2002. Management implications of the distribution of fruit set on breadfruit (Artocaprus altilis) trees. In Proceedings of the XXVI International Horticultural Congress: Citrus and other subtropical and tropical fruit crops: Issues, advances and opportunities. Acta Horticulturae 623:201-207.

Roberts-Nkrumah, L.B. 2007. An overview of breadfruit (Artocarpus altilis) in the Caribbean. In Proceedings of the 1st International Symposium on Breadfruit Research and Development. Acta Horticulturae 757:51-60.

Rouse-Miller, J. \& J.E. Duncan. 2000. In vitro propagation of Artocarpus altilis (Park.) Fosberg (breadfruit) from mature plant material. In Vitro Cellular \& Developmental Biology-Plant 36(2), 115-117.

Rowe-Dutton, P. 1976. Artocarpus heterophyllus-Jackfruit. Pp. 269-290 in The Propagation of Tropical Fruit Trees. Edited by R.J. Garner \& S.A. Chaudhuri, CABI Publishing, London.

Sagita, D. 2009. Scientists on Indonesia's Plant Science Frontier Reporting Fruitful Results. Jakarta Globe. www. thejakartaglobe.com/indonesia/scientists-on-indonesiasplant-science-frontier-reporting-fruitful-results/18325
Sankat, C. \& V. Maharaj. 2007. A review of postharvest storage technology of breadfruit. In Proceedings of the 1st International Symposium on Breadfruit Research and Development. Acta Horticulturae 757:183-192.

Sauerborn, J. 2002. Site productivity, the key to crop productivity. Journal of Agronomy and Crop Science 188(6):363-367.

Sharma, M.R. 1965. Morphological and anatomical investigations on Artocarpus Forst. IV The Flower. Phytomorphology 15(2):185-201.

Shi, W.L., P.K. Saxena, S.J. Murch \& D. Ragone. 2007. Mass-propagation and bioreactor-based technologies for germplasm conservation, evaluation and international distribution of breadfruit. In Proceedings of the 1st International Symposium on Breadfruit Research and Development. Acta Horticulturae 757:169-176.

Shimizu, K., M. Fukuda, R. Kondo \& K. Sakai. 2000. The 5a-reductase inhibitory components from heartwood of Artocarpus incisus. Planta Medica 66:16-19.

Simpson, B.B. \& M.C. Ogorzaly. 2000 Economic Botany: Plants in our world. McGraw-Hill, Toronto, Canada.

Smith, N.J.H., J.T. Williams, D.L. Plucknett \& J.P. Talbot. 1992. Tropical Forests and their Crops. Comstock Publishing Associates Ithaca, New York.

Tenenbaum D.J. 2008. Food vs. fuel: Diversion of crops could cause more hunger. Environmental Health Perspectives 116(6):A257-A257.

Trindade, M.B., J.L.S. Lopes, A. Soares-Costa, A.C. Monteiro-Moreira, R.A. Moreira, M.L.V. Oliva \& L.M. Beltramini. 2006. Structural characterization of novel chitin-binding lectins from the genus Artocarpus and their antifungal activity. BBA-Proteins and Proteomics 1764(1):146-152.

Tuia, V.S., M.B. Taylor \& D. Ragone. 2007. Studies on in vitro culture of breadfruit cultivars in the Pacific. In Proceedings of the 1st International Symposium on Breadfruit Research and Development. Acta Horticulturae 757:161168.

Walter A. 1989 Notes sur les cultivars d'arbre a pain dans le Nord de Vanuatu. Journal de la Société des Océanistes $1(2): 3-18$.

Wang, Y., T. Deng, L. Lin, Y. Pan \& X. Zheng. 2006. Bioassay-guided isolation of antiatherosclerotic phytochemicals from Artocarpus altilis. Phytotherapy Research 20(12):1052. 


\section{Jones et al. - Beyond the Bounty: Breadfruit (Artocarpus altilis) for food security and novel foods in the $21^{\text {st }}$ Century}

Wang, Y., K. Xu, L. Lin, Y. Pan \& X. Zheng. 2007. Geranyl flavonoids from the leaves of Artocarpus altilis. Phytochemistry 68(9):1300-1306.

Webster, S.A. 2006. The Breadfruit in Jamaica: A commercial and horticultural perspective. Seymour Webster, Port Antonio, Jamaica.

Weiner, M.A. 1984. Secrets of Fijian Medicine. Weiner, M.A., Berkeley, California.

Whistler, W.A. 2001. Plants in Samoan Culture: The ethnobotany of Samoa. The University of Hawaii Press, Honolulu, Hawai i.

Wilder, G.P. 1928. The Breadfruit of Tahiti. Bernice P Bishop Museum Press, Honolulu, Hawaii.

Wootton, M. \& F. Tumaalii. 1984. Composition of flours from Samoan breadfruit. Journal of Food Science 49(5):1396-1397.
World Bank. 2007. World Development Report 2008: Agriculture for Development. The World Bank, Washington, D.C.

Worrell, D.B., C.M.S. Carrington \& D.J. Huber. 2002. The use of low temperature and coatings to maintain storage quality of breadfruit, Artocarpus altilis (Parks.) Fosb. Postharvest Biology and Technology 25(1):33-40.

Zerega, N.J.C., D. Ragone \& T.J. Motley. 2004. Complex origins of breadfruit (Artocarpus altilis, Moraceae): Implications for human migrations in Oceania. American Journal of Botany 91(5):760-766.

Zerega, N.J.C., D. Ragone \& T.J. Motley. 2005. Systematics and species limits of breadfruit (Artocarpus, Moraceae). Systematic Botany 30(3):603-615.

Zerega, N., D. Ragone \& T.J. Motley. 2006. Breadfruit origins, diversity, and human-facilitated distribution. Pp. 213238 in Darwin's Harvest: New approaches to the origins, evolution, and conservation of crops. Edited by T.J. Motley, N. Zerega \& H. Cross. Columbia University Press, New York. 
